\title{
Effects of N:P:Si ratios and zooplankton grazing on phytoplankton communities in the northern Adriatic Sea. I. Nutrients, phytoplankton biomass, and polysaccharide production
}

\author{
Edna Granéli ${ }^{1, *}$, Per Carlsson ${ }^{1}$, Jefferson T. Turner ${ }^{2}$, Patricia A. Tester ${ }^{3}$, \\ Christian Béchemin ${ }^{4}$, Rodger Dawson ${ }^{5}$, Enzo Funari ${ }^{6}$
}

\author{
${ }^{1}$ University of Kalmar, Department of Marine Sciences, POB 905, S-391 29 Kalmar, Sweden \\ ${ }^{2}$ Biology Department, University of Massachusetts Dartmouth, North Dartmouth, Massachusetts 02747, USA \\ ${ }^{3}$ National Marine Fisheries Service, NOAA, Southeast Fisheries Science Center, Beaufort Laboratory, Beaufort, \\ North Carolina 28516, USA \\ ${ }^{4}$ CREMA - L'Houmeau (CNRS-IFREMER), BP5, F-17137 L'Houmeau, France \\ ${ }^{5}$ Chesapeake Biological Laboratory, University of Maryland, Solomons, Maryland 20688, USA \\ ${ }^{6}$ Laboratorio di Igiene Ambientale, Istituto di Sanita, Viale R. Elena 299, I-00161 Rome, Italy
}

\begin{abstract}
The northern Adriatic Sea has been historically subjected to phosphorus and nitrogen loading. Recent signs of increasing eutrophication include oxygen deficiency in the bottom waters and large-scale formation of gelatinous macroaggregates. The reason for the formation of these macroaggregates is unclear, but excess production of phytoplankton polysaccharides is suspected. In order to study the effect of different nutrient (nitrogen:phosphorus:silicon) ratios on phytoplankton production, biomass, polysaccharides, and species succession, 4 land-based enclosure experiments were performed with northern Adriatic seawater. During 2 of these experiments the importance of zooplankton grazing as a phytoplankton loss factor was also investigated. Primary productivity in the northern Adriatic Sea is thought to be phosphorus limited, and our experiments confirmed that even low daily phosphorus additions increased phytoplankton biomass. However, this only occurred when nitrogen additions were high. Alternatively, when nitrogen was added in low concentrations, with simultaneous high phosphorus additions, phytoplankton biomass declined. Nitrogen deficiency induced the highest production of polysaccharides per unit of cell carbon, while nutrient-sufficient and phosphorus-deficient treatments caused a higher production of polysaccharides in total. In order to decrease the frequency of algal blooms and high polysaccharide production in the northern Adriatic, it appears necessary to reduce the amounts of incoming nutrients. Since phosphorus has a high turnover rate in low $P:$ high $N$ waters of the northern Adriatic, and since our experiments show that a shortage of nitrogen can produce reduced levels of phytoplankton biomass and total polysaccharides, a reduction of the nitrogen discharge would probably be the best countermeasure for eutrophication in the northern Adriatic Sea.

KEY WORDS: Adriatic Sea - Nitrogen · Silicon - Limitation · Phytoplankton · Phosphorus - Polysaccharide - Chemical composition
\end{abstract}

\section{INTRODUCTION}

Eutrophication due to anthropogenic nutrient loading in coastal marine waters is a growing problem throughout the world (Likens 1972, Caraco et al. 1990, Nixon 1990, Vollenweider et al. 1992). The northern

\footnotetext{
·E-mail: edna.graneli@ng.hik.se
}

Adriatic Sea has been undergoing eutrophication for decades due to large loadings of phosphorus $(\mathrm{P})$ and nitrogen $(\mathrm{N})$ originating from agriculture, industries and sewage (Justic 1987). Although anoxic events in the bottom waters of the northern Adriatic Sea have occurred sporadically for several centuries (Piccinetti \& Manfrin 1969), the frequency of occurrence and size of the areas exhibiting oxygen deficiency have dramati- 


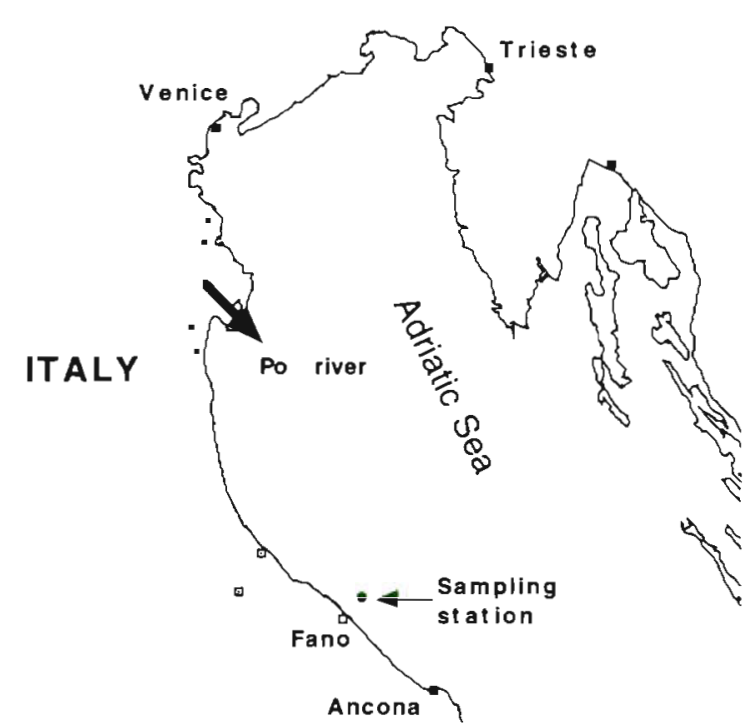

Fig. 1. Location of the sampling station for the water used in the enclosure experiments

cally increased during the last 2 decades (Justic 1987, 1991).

Another possible sign of increasing eutrophication in these waters is formation of gelatinous macroaggregates of huge proportions, known locally as 'mare sporco' or 'dirty water' (Stachowitsch et al. 1990, Marchetti 1992). These gelatinous masses are thought to be related to phytoplankton blooms, and have caused beach fouling throughout the northern Adriatic Sea, with substantial economical losses for an otherwise flourishing tourism industry. These phenomena have not been associated with severe oxygen deficiency, however, probably due to the low content of organic matter in the gelatinous mass (Marchetti 1992). However, oxygen deficiency has been observed in the bottom waters after large accumulations of gelatinous macroaggregates during the summers of 1988 and 1989 (Degobbis 1989). Other harmful blooms occurring in this area include those of toxic phytoplankton species (Boni et al. 1993, Fonda Umani et al. 1993).

The main source of nutrients for the northern Adriatic Sea is the Po River (Degobbis \& Gilmartin 1990, Vollenweider et al. 1992), with a mean discharge of about $1500 \mathrm{~m}^{3} \mathrm{~s}^{-1}$ (Cati 1981) of water containing high concentrations of $\mathrm{N}$ and $\mathrm{P}$. The total amount of $\mathrm{P}$ reaching the northern Adriatic is approximately 30000 tons $\mathrm{yr}^{-1}$, of which the Po River contributes about $60 \%$ (Chiaudani \& Vighi 1982). Approximately 152000 tons $\mathrm{yr}^{-1}$ of $N$ reaches coastal waters, of which $75 \%$ is discharged by the Po River (Chiaudani et al. 1980a). The large transport of nutrients to the relatively shallow sea, markedly increases the primary production in these waters (Gilmartin \& Revelante 1980, Malej et al. 1995).
For most marine coastal waters and inland seas $\mathrm{N}$ is thought to be the most limiting nutrient for phytoplankton production (Ryther \& Dunstan 1971, Howarth 1988, Granéli et al. 1990, Oviatt et al. 1995). However, a few cases have been reported where P limits production (Berland et al. 1980, Smith 1984), and P has been suggested to be limiting in marine coastal waters only when large nutrient loads with high N:P ratios reach coastal waters (Howarth 1988).

Phosphorus has been suggested to be the most limiting nutrient for phytoplankton primary production in the northern Adriatic Sea. Indeed, $80 \%$ of the inorganic N:P ratios found in the surface waters suggest that $P$ is limiting phytoplankton growth (Chiaudani et al. 1980b), and bioassay experiments have confirmed a marked stimulation of phytoplankton growth when $\mathrm{P}$ was added (Pojed \& Kveder 1977).

The main objectives of our experiments were to investigate: (1) the effects of different N, P and silicon (Si) ratios and concentrations on phytoplankton growth, biomass, production, polysaccharide production, biochemical composition and changes in the intracellular content of carbon (C), N and $\mathrm{P}_{\text {; }}$ (2) the effects of these nutrient manipulations on the abundance and composition of natural phytoplankton communities; and (3) the impact of zooplankton grazing on these phytoplankton communities.

Experiments were performed in May 1993, June 1993, May 1994 and August 1994 in land-based enclosures in Fano, Italy. Nutrient, phytoplankton biomass, primary production and polysaccharide production results for the June 1993, May 1994 and August 1994 experiments will be presented in this paper. Effects of different nutrient ratios and concentrations on phytoplankton species composition in the June 1993 and May 1994 experiments will be presented in the second paper in this series (Carlsson \& Granéli 1999, in this issue). Fluctuations of zooplankton in enclosures and results of zooplankton grazing experiments from the May 1993 and June 1993 experiments will be presented in the third paper in this series (Turner et al. 1999, in this issue).

\section{MATERIALS AND METHODS}

Experiments were performed in land-based enclosures using northern Adriatic seawater. The construction of this land-based enclosure system has been previously described in Olsson et al. (1992). The water containing the natural phytoplankton communities was pumped from 1 to $2 \mathrm{~m}$ depth from a station $15 \mathrm{~km}$ off the east coast of Italy, offshore from Fano (Fig. 1), and filled into $500 \mathrm{l}$ dark-blue plastic containers. While filling the tanks on board the ship, the water 
was filtered through $100 \mu \mathrm{m}$ mesh in order to remove extraneous mesozooplankton. We realized that this sieving could also remove some chain-forming diatoms, if present, but since initial inspections revealed that the phytoplankton was dominated by small microflagellates, we considered that removal of extraneous grazers from the containers was more important than the error caused by possibly removing some chain-forming diatoms. The containers were lifted from the ship and placed on a truck for immediate transport to the experimental site (this procedure lasted for about $1 \mathrm{~h}$ and there was no significant temperature change in the water). The enclosures consisted of 100 l white polyethylene cylinders with lids, and the cylinders were immersed in a plastic swimming pool supplied with running water in order to keep the temperature inside the cylinders close to the temperature of the surrounding sea $\left(15\right.$ to $18^{\circ} \mathrm{C}$ in May 1994,21 to $24^{\circ} \mathrm{C}$ in June 1993 , and 24 to $31^{\circ} \mathrm{C}$ in August 1994). At the experimental site, the water was transferred from the tanks to the cylinders by siphoning using a $40 \mathrm{~mm}$ diameter tube. Water was filled into each cylinder for $20 \mathrm{~s}$ at a time, continuously alternating between the cylinders. In this way the cylinders were filled with equal amounts of water from the different $500 \mathrm{l}$ plastic transport containers and any initial patchiness in the sampled water was integrated.

After filling the cylinders with $100 \mathrm{l}$ of seawater, samples were taken from all the cylinders for immediate analyses of nutrients $\left(\mathrm{NO}_{3}, \mathrm{NH}_{4}, \mathrm{PO}_{4} \text { and } \mathrm{Si}(\mathrm{OH})_{4}\right)_{\text {, }}$ chlorophyll a (chl a), primary production, and particulate $\mathrm{C}, \mathrm{N}$ and $\mathrm{P}$. The phytoplankton communities were exposed to different N:P:Si regimes (Table 1). Based on the concentrations found for the different nutrients in the collected water, additions of $\mathrm{PO}_{4}, \mathrm{NO}_{3}$ and $\mathrm{Si}(\mathrm{OH})_{4}$ were made to the different cylinders in order to obtain different nutrient ratios in the May 1994, June 1993, and August 1994 experiments. In the May 1993 experiment a surplus of macro- and micronutrients was added (see Carlsson \& Granéli 1999, Turner et al. 1999). Each treatment was performed in triplicate cylinders. Iron, EDTA and trace metals (Cu, Zn, Co, $\mathrm{Mn}$ and $\mathrm{Mo}$ ) were added at concentrations corresponding to $1 / 20$ of the culture medium 'f' (Guillard \& Ryther 1962), in order to prevent any limitation of phytoplankton growth by these substances. For the same reason, vitamins (B12, biotin and thiamin) were added according to Schöne \& Schöne (1982) (as 1/20 of the original description).

Table 1. Nutrient concentrations in the initial water used in the experiments and the different concentrations reached in the experimental cylinders after nutrient additions. The nutrient additions were either made as 1 initial addition (Expt 1) or as daily additions (Expts 2 and 3). In Expts 2 and 3 the limiting nutrient was added daily while the other nutrients that were in excess were added only when their concentrations were significantly reduced. In the $\mathrm{N}$-deficient Expt 1 treatments, no addition of nitrate was made until the concentration of inorganic nitrogen (nitrate + ammonium) had decreased to $1 \mu \mathrm{M}$

\begin{tabular}{|c|c|c|c|c|c|}
\hline Treatment & & $\mathrm{PO}_{4}(\mu \mathrm{M})$ & $\mathrm{NO}_{3}(\mu \mathrm{M})$ & $\mathrm{SiO}_{2}(\mu \mathrm{M})$ & $\mathrm{NH}_{4}(\mu \mathrm{M})$ \\
\hline \multicolumn{6}{|l|}{ June 1993 Expt 1} \\
\hline \multirow[t]{2}{*}{ Initial concentrations } & Mean & 0.21 & 1.03 & 4.23 & 1.02 \\
\hline & SD & 0.01 & 0.52 & 0.08 & 0.09 \\
\hline P-deficient & & 1 & 40 & 40 & \\
\hline N-deficient & & 2 & 20 & 40 & \\
\hline Si-deficient & & 2 & 40 & 20 & \\
\hline Nutrient sufficient & & 2 & 40 & 40 & \\
\hline \multicolumn{6}{|l|}{ May 1994 Expt 2} \\
\hline \multirow[t]{2}{*}{ Initial concentrations } & Mean & 0.12 & 3.33 & 1.39 & 0.46 \\
\hline & $\mathrm{SD}$ & 0 & 0.12 & 0.03 & 0.01 \\
\hline P-deficient & 0.2 & 0.2 & 20 & 20 & \\
\hline P-deficient & 0.8 & 0.8 & 20 & 20 & \\
\hline N-deficient & 1 & 1.3 & 1 & 20 & \\
\hline N-deficient & 4 & 1.3 & 4 & 20 & \\
\hline Si-deficient & 1 & 1.3 & 20 & 1 & \\
\hline Si-deficient & 4 & 1.3 & 20 & 4 & \\
\hline Nutrient sufficient & 5 & 0.3 & 5 & 5 & \\
\hline Nutrient sufficient & 20 & 1.3 & 20 & 20 & \\
\hline \multicolumn{6}{|l|}{ August 1994 Expt 3} \\
\hline \multirow[t]{2}{*}{ Initial concentrations } & Mean & 0.14 & 1.21 & 0.72 & 0.77 \\
\hline & $\mathrm{SD}$ & 0 & 0.20 & 0.08 & 0.05 \\
\hline P-deficient & 0.2 & 0.2 & 20 & 20 & \\
\hline $\mathrm{N}$-deficient & 1 & 1.3 & 1 & 20 & \\
\hline Si-deficient & 1 & 1.3 & 20 & 1 & \\
\hline Nutrient sufficient & 20 & 1.3 & 20 & 20 & \\
\hline
\end{tabular}




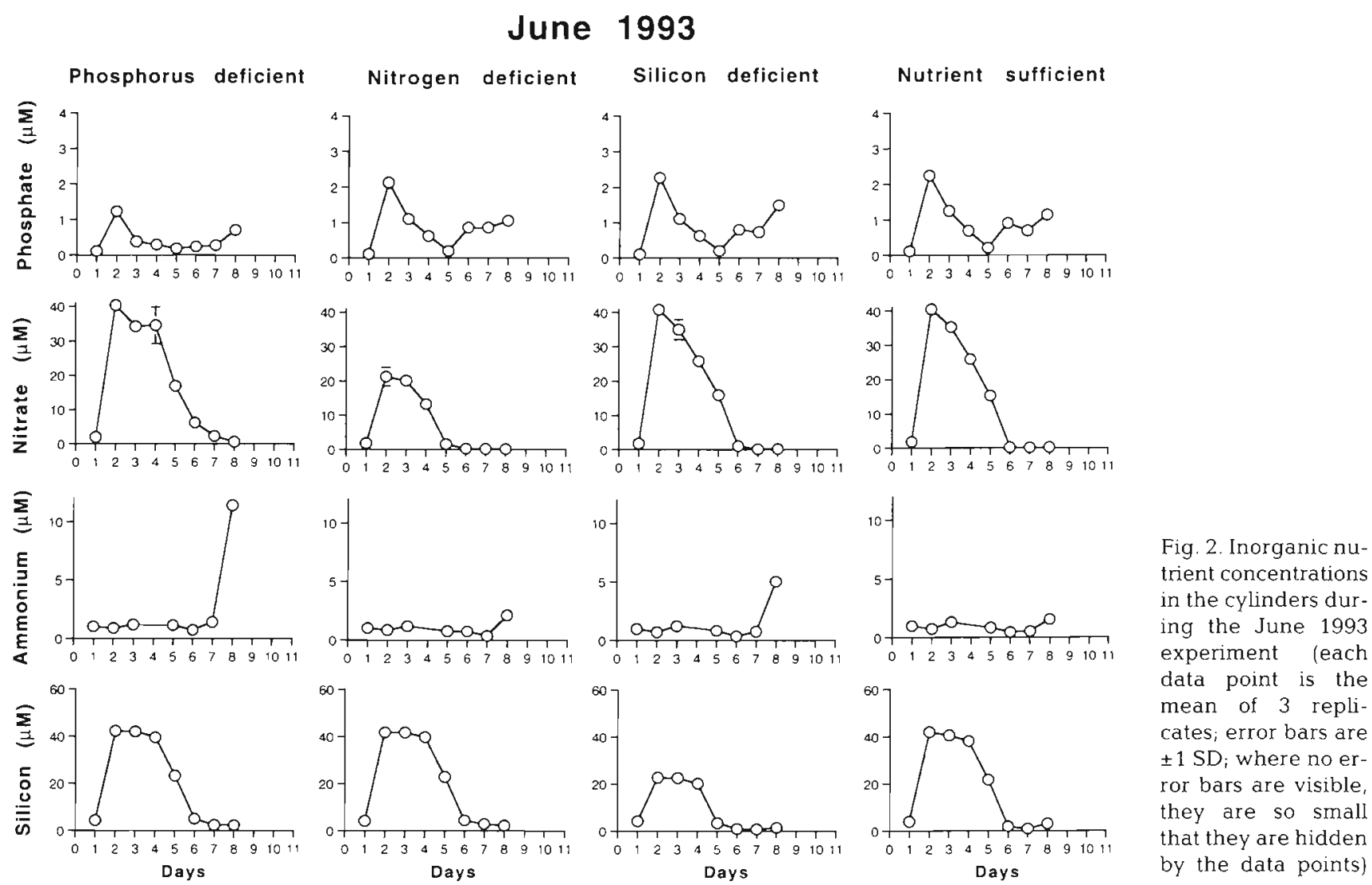

In the 1994 experiments, the water in the cylinders was filtered once more through a $100 \mu \mathrm{m}$ nylon net after $3 \mathrm{~d}$. This was done in order to remove the copepods that had developed from nauplii and eggs that passed through the initial sieving. This second filtration procedure was designed to prevent a copepod population from developing in the cylinders during the sampling period (as had occurred in the 1993 experiments). The pool was covered with a black plastic net (mesh size of approximately $0.5 \mathrm{~cm}$ ) that, together with the white plastic lids, decreased the light intensity by 65 to $70 \%$. This was expected to prevent photoinhibition and excessive solar heating of the phytoplankton.

Samples were taken daily for analyses of nutrients $\left(\mathrm{NO}_{3}, \mathrm{NH}_{4}, \mathrm{PO}_{4}\right.$ and $\left.\mathrm{Si}(\mathrm{OH})_{4}\right)$, chl a concentrations, and for identification and counting of phytoplankton cells (see Carlsson \& Granéli 1999).

Primary production was measured, and samples were filtered onto precombusted Gelman A/E filters $\left(450^{\circ} \mathrm{C}, 2 \mathrm{~h}\right)$ for analyses of particulate $\mathrm{C}, \mathrm{N}$ and $\mathrm{P}$ was also performed at least every third day. In the May 1994 experiment, samples were also taken every third day for polysaccharide analyses by the methods of Dawson \& Liebezeit (1981).

Nutrients were analyzed manually following methods of Valderrama (1995). Chl a was measured in a
Turner fluorometer model $10 \mathrm{AU}$ after extraction in dark for at least $12 \mathrm{~h}$ with $95 \%$ ethanol according to the method of Jespersen \& Christoffersen (1987). Fluorescence units were transformed to $\mu \mathrm{g}^{-1}$ of chl a after spectrophotometric analysis of extracted chl a using the initial water used in the experiments. Primary production was measured as ${ }^{14} \mathrm{C}$-uptake using the method of Extebjerg-Nielsen \& Bresta (1984). Two $\mu \mathrm{Ci}$ of radioactive $\mathrm{NaH}^{14} \mathrm{CO}_{3}$ were added to $25 \mathrm{ml}$ glass flasks containing sample water and incubated in the center of each cylinder at $0.5 \mathrm{~m}$ depth for $2 \mathrm{~h}$ (usually between 10:00 and 12:00 h). One light bottle was incubated for each cylinder and 1 dark bottle was incubated for each treatment. Primary production was calculated as $\mu \mathrm{g} C$ $\mathrm{l}^{-1} \mathrm{~h}^{-1}$ (dark bottle values were subtracted from light bottle values).

Light was measured with a QSL-100 spherical quantameter (Biospherical Instruments Inc., San Diego). Light intensity, measured as photosynthetically active radiation (PAR), varied between 80 and $1200 \mathrm{pmol} \mathrm{m}^{-2}$ $\mathrm{s}^{-1}$ in the center of the cylinders during the incubations, depending on the time of day and the degree of cloudiness. Analyses of particulate $\mathrm{C}$ (POC) and $\mathrm{N}$ (PON) were done using a Fisons $\mathrm{CHN}$ analyser model 1108 and the analyses of particulate P (POP) followed the method of Solorzano \& Sharp (1980). 


\section{RESULTS}

\section{Nutrients}

In the June 1993 experiment, nutrient declines reflected heavy phytoplankton utilization. Phosphate decreased to low values $\left(<0.25 \mu \mathrm{mol} \mathrm{l^{-1 }}\right)$ from Days 4 to 6 in the P-deficient treatment (Fig. 2). For nitrate the concentrations became low $\left(<0.5 \mu\right.$ mol $\left.\mathrm{l}^{-1}\right)$ in the $\mathrm{N}$-deficient treatment between Days 6 and 8, while Si reached a minimum of $0.8 \mu \mathrm{mol} \mathrm{l}^{-1}$ on Days 7 and 8 in the Si-deficient treatment. In all treatments, including the 'nutrient-sufficient' cylinders where N:P:Si was added corresponding to the Redfield ratio, there was probably nitrate deficiency between Days 6 and 8, even if nitrate was added in surplus (N:P ratio 40:1 and N:Si ratio 40:2 in the P-deficient and Si-deficient treatments, respectively) at the beginning of the experiment. The low concentrations of nitrate in all treatments possibly resulted in the phytoplankton being under physiological stress, and increased heterotrophic activity could have led to the observed increases in ammonium concentrations on the last day of the experiment (Fig. 2).

In the May 1994 experiment (Fig. 3), each of the different deficient nutrients and the 'balanced' nutrients were supplied at 2 levels, 1 low and 1 higher. In the Pdeficient treatments $\left(0.2\right.$ and $\left.0.8 \mu \mathrm{mol} \mathrm{l^{-1 }} \mathrm{PO}_{4} \mathrm{~d}^{-1}\right)$ phosphate was probably limiting phytoplankton growth during Days 6, 7 and 8 in both treatments. Phosphate concentration also became very low and probably limited phytoplankton growth in the Si-deficient cylinders where Si was added to reach a concen-

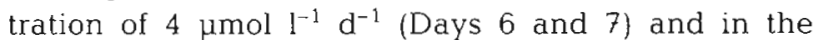
nutrient-sufficient treatment (N:P:Si $=5: 0.3: 5 \mu \mathrm{mol} \mathrm{l}^{-1}$ $\mathrm{d}^{-1}$ ), for Days 6 to 10 . In all other treatments phosphate concentrations were always above limitation levels. Nitrate concentrations decreased to the detec-

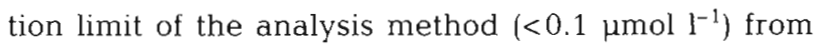
Days 5 to 10 for both $\mathrm{N}$-deficient treatments, i.e. in the cylinders where nitrate was added to reach concentrations of 1 or $4 \mu \mathrm{mol} \mathrm{l}^{-1} \mathrm{NO}_{3} \mathrm{~d}^{-1}$. Also, in the treatments N:P:Si 5:0.3:5 and 20:1.3:20, the nitrate concentrations became lower than $0.1 \mu \mathrm{mol} \mathrm{l}^{-1}$. The phytoplankton was never able to reduce the concentration of Si below $0.55 \mu \mathrm{mol} \mathrm{l}^{-1}$. This concentration was measured from Days 5 to 10 for both treatments with Si deficiency and in the N:P:Si 5:0.3:5 treatment. Measurements of low concentrations of Si $<<0.1 \mu \mathrm{mol}$ $\mathrm{l}^{-1}$ ) in blanks prepared in artificial seawater were routinely performed without any problems. Ammonium
May 1994
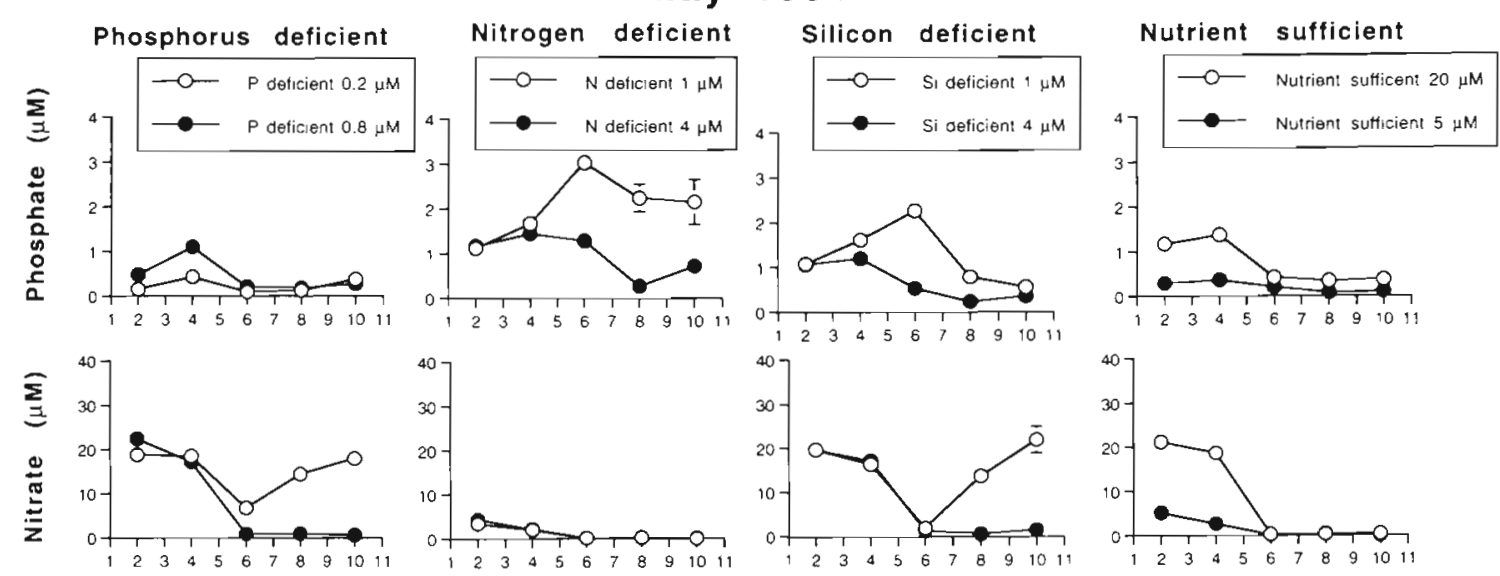

Fig. 3. Inorganic nutrient concentrations in the cylinders during the May 1994 experiment leach data point is the mean of 3 replicates; error bars are $\pm 1 \mathrm{SD}_{\text {; }}$ where no error bars are visible, they are so small that they are hidden by the data points)
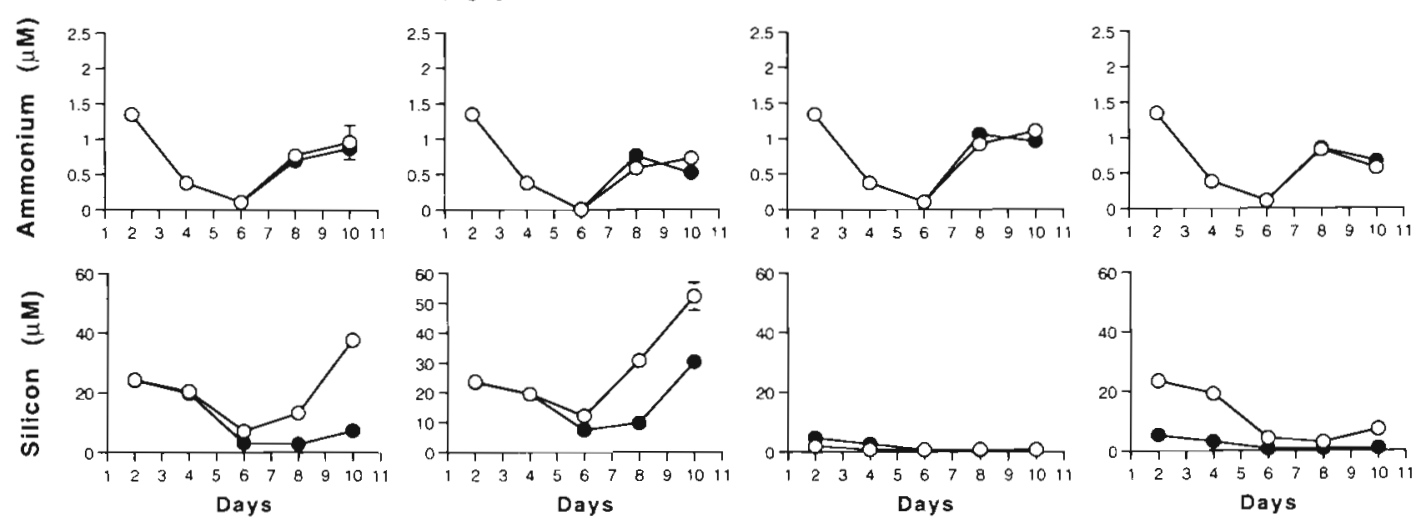


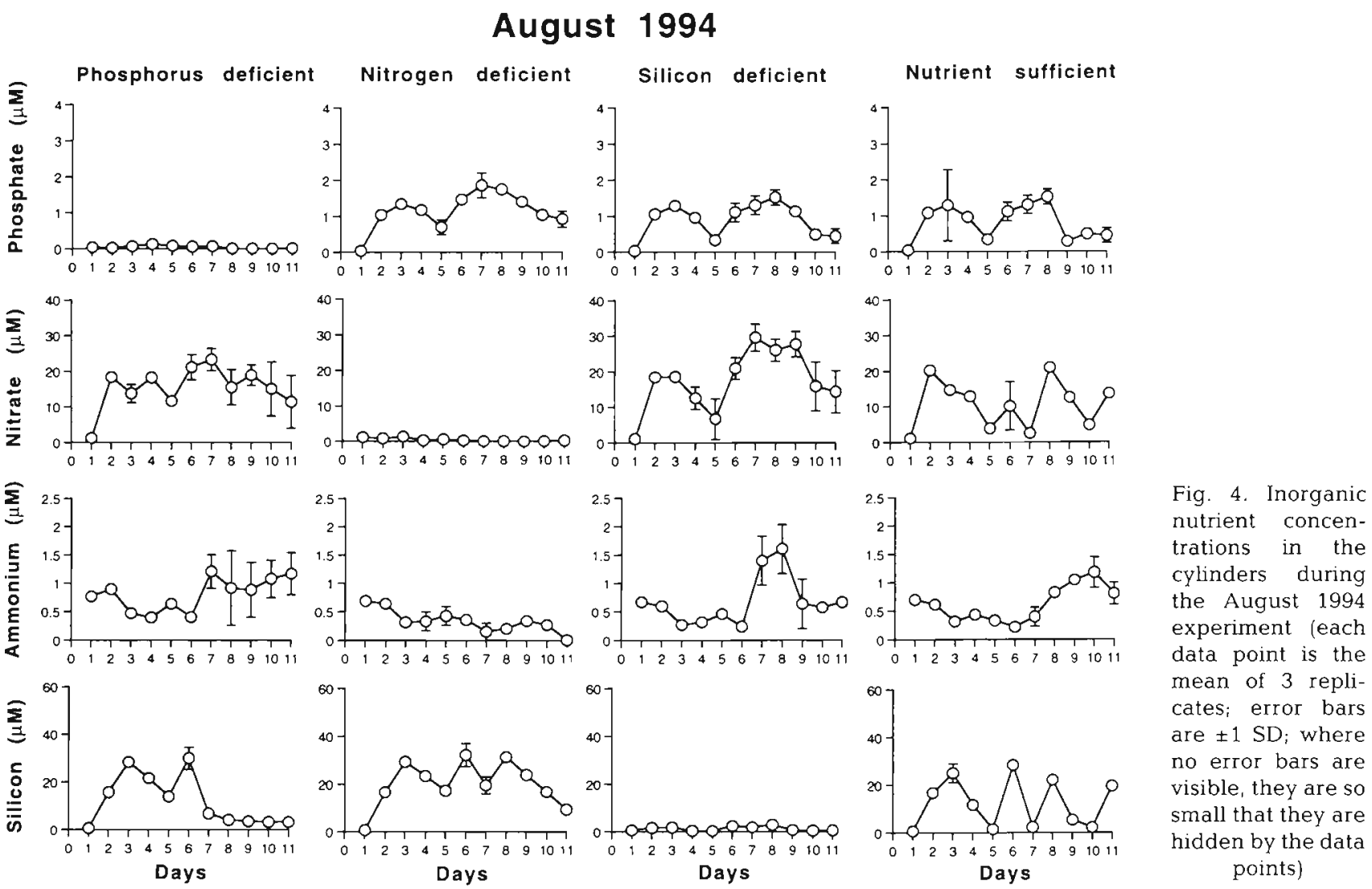

concentrations decreased in all treatments and even to the detection limit of the analysis method at Day 6 in the $\mathrm{N}$-deficient treatments. However, in all the treatments ammonium increased from Day 7 until the end of the experiment.

In the August 1994 experiment (Fig. 4) phosphate and nitrate were probably limiting phytoplankton growth in their respective P- or N-deficient treatments from Days 5 to 11 . Only by the last 2 days did Si reach the same low concentrations found in the May 1994 experiment, i.e. about $0.55 \mu \mathrm{mol} \mathrm{l}^{-1}$. In this experiment ammonium was reduced to very low or zero values in the $N$ deficient treatment, while in the other treatments the ammonium concentrations increased from Day 7 until the end of the experiment, as in the other experiments.

\section{Chl a}

In the June 1993 experiment, chl a concentrations in the nutrient-sufficient and the Si-deficient cylinders increased to maximum values of $45.6 \pm 7.9$ (mean \pm SD) and $41.7 \pm 8.2 \mu \mathrm{gl}^{-1}$, respectively (Fig. 5). In the P- and $\mathrm{N}$-deficient cylinders, somewhat lower chl a concentrations of $32.8 \pm 6.4$ and $32.4 \pm 1.1$, respectively, were found as maximum values on Day 6 of the experiment.
In the May 1994 experiment, the 2 levels of $\mathrm{N}$ deficiency ( 1 and $4 \mu \mathrm{mol} \mathrm{l}^{-1} \mathrm{NO}_{3}$ added daily) produced the lowest maximum values of all the treatments, 9.1 and $22.1 \mu \mathrm{g} \mathrm{l}^{-1}$ of chl a, respectively (Fig. 5). The nutrientsufficient treatments supplied with the low addition of nutrients (N:P:Si $=5: 0.3: 5$ ) produced a maximum value slightly higher than that produced by the $4 \mu \mathrm{mol} \mathrm{l}^{-1} \mathrm{~N}$ deficient treatment $\left(25.5 \mu \mathrm{g} \mathrm{l}^{-1}\right)$. The treatments where phosphate and Si were added at low levels (additions of $0.2 \mu \mathrm{mol} \mathrm{l}^{-1} \mathrm{P}$ and $1 \mu \mathrm{mol} \mathrm{l}^{-1} \mathrm{Si} \mathrm{d}^{-1}$, respectively) produced higher concentrations of chl a (44.6 \pm 3.3 and $43.2 \pm 1.7 \mathrm{mg} \mathrm{l}^{-1}$, respectively). The highest chl a concentrations were found in the nutrient-sufficient treatment with a higher addition of nutrients (N:P:Si = 20:1.3:20), and in the P-deficient treatment supplied with $0.8 \mu \mathrm{mol} \mathrm{I}^{-1} \mathrm{P} \mathrm{d}^{-1}: 121.4 \pm 3.9$ and $98.1 \pm 6.9 \mu \mathrm{g} \mathrm{l}^{-1}$, respectively.

In the August 1994 experiment, $\mathrm{N}$ deficiency $(1 \mu \mathrm{mol}$ $\mathrm{l}^{-1} \mathrm{NO}_{3}$ added daily) again caused the lowest chl a concentrations found in all the treatments $(11.1 \pm 1.5 \mu \mathrm{g}$ $\mathrm{l}^{-1}$ ) (Fig. 5). The treatment with the second lowest chl a concentration was the Si-deficient treatment $(1 \mu \mathrm{mol}$ $\mathrm{l}^{-1} \mathrm{Si}$ added daily), where maximum chl a values were 3 times higher than the maximum found in the N-deficient treatment $\left(39.0 \pm 1.4 \mu \mathrm{g} \mathrm{l}^{-1}\right)$. The highest chl a concentrations were found in the P-deficient and nutri- 
Fig. 5. Chlorophyll a concentrations in the cylinders during the June 1993, May 1994 and August 1994 experiments (each data point is the mean of 3 replicates; error bars are $\pm 1 \mathrm{SD}$; where no error bars are visible, they are so small that they are hidden by the data points)
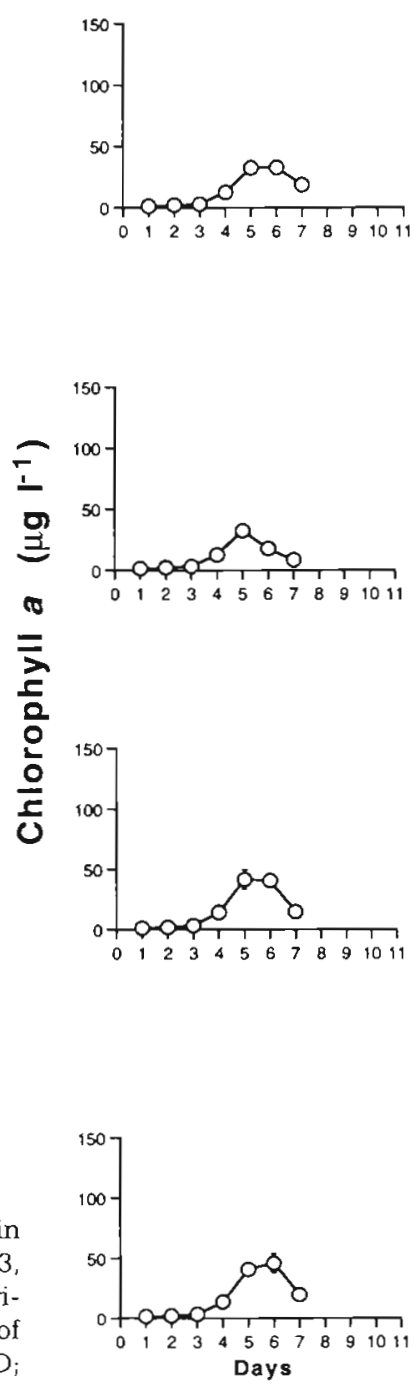

June 1993

\section{Phosphorus deficient}
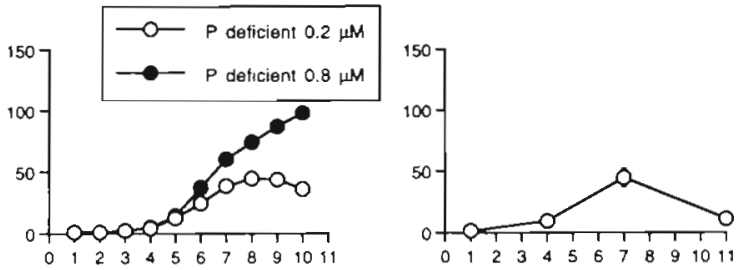

Nitrogen deficient
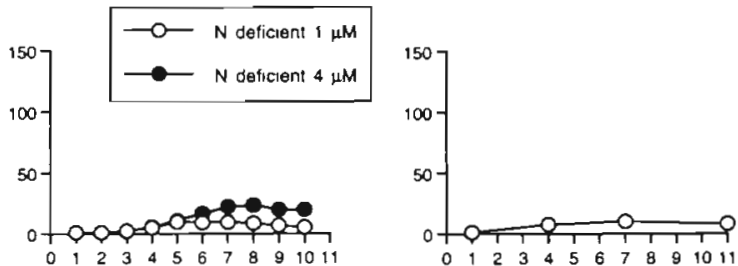

\section{Silicon deficient}
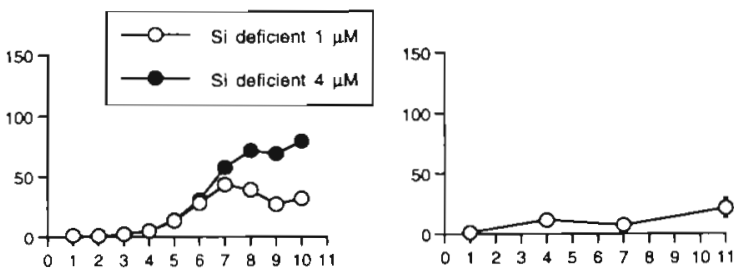

- Nutrient sufficient

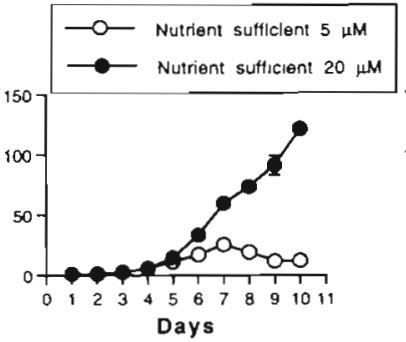

May 1994

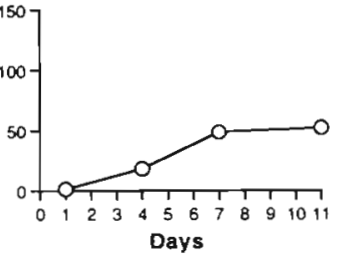

August 1994

ent-sufficient treatments $\left(56.3 \pm 5.1 \mathrm{\mu g} \mathrm{l}^{-1}\right.$ and $68.5 \pm$ 6.0 , respectively).

\section{Primary production}

The primary production rates followed the same trends as the chl $a$ in the different nutrient treatments in all experiments, i.e. the lowest $C$ uptake was found in the $\mathrm{N}$ - followed by the P-and Si-deficient cylinders, and the highest values were measured in the nutrient sufficient cylinders (Fig. 6). When the inorganic nutrients became deficient in the June 1993 experiment, primary production started to decrease $1 \mathrm{~d}$ before chl a concentrations dropped.

\section{Growth rates}

Based on increases in the phytoplankton cell $C$ (see Carlsson \& Granéli 1999) and chl a, the nutrient-sufficient treatments induced the highest rates of cell division, followed by the treatments with Si- and P-deficient conditions. The lowest growth rates were found when $\mathrm{N}$ was the deficient nutrient (Table 2).

\section{Influence of nutrient ratios and concentrations on phytoplankton species composition}

The general trend from these experiments was that small flagellates and diatoms from a few genera 


\section{Phosphorus deficient}
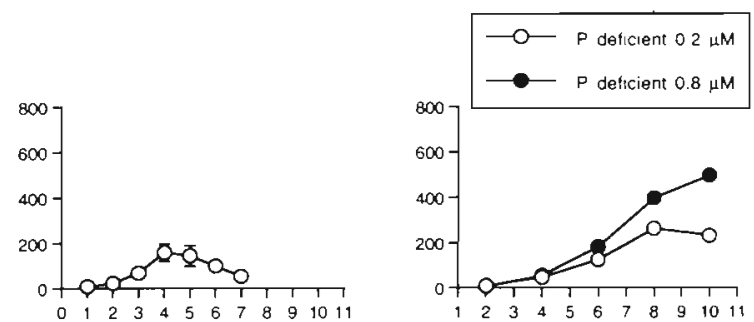

Nitrogen deficient

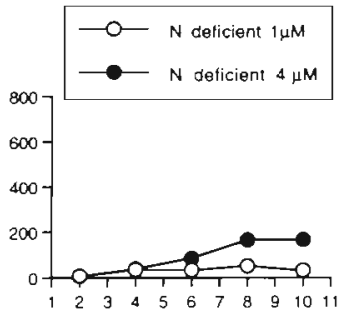

\section{Silicon deficient}
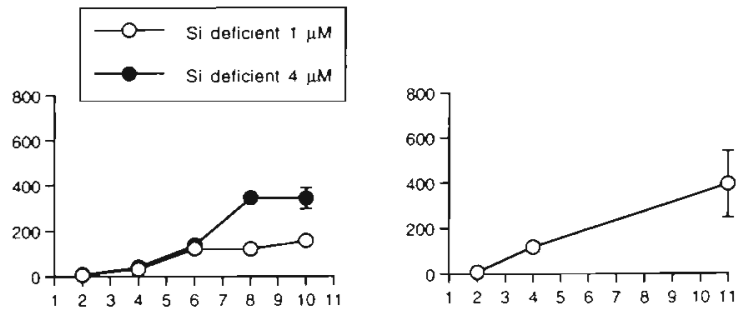

Nutrient sufficient

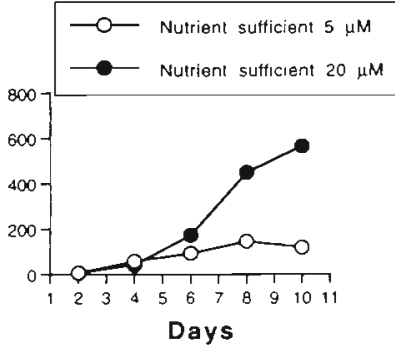

May 1994

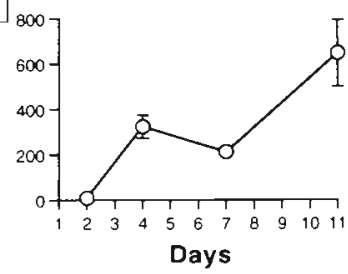

August 1994
Fig. 6. Primary production in the cylinders during the June 1993 , May 1994 and August 1994 experiments (each data point is the mean of 3 replicates; error bars are $\pm 1 \mathrm{SD}$; where no error bars are visible, they are so small that they are hidden by the data points)
Table 2. Growth rates (divisions $\mathrm{d}^{-1}$ ) based on increase in cell carbon and chlorophyll content for the phytoplankton communities in the exponential growth phase in the May 1994 mesocosm experiment

\begin{tabular}{|lccc|}
\hline & & Carbon & Chl $a$ \\
\hline Nutrient sufficient & 1.25 & 1.70 \\
Si-deficient & $\left(1.0 \mu \mathrm{M} \mathrm{Si} \mathrm{d}^{-1}\right)$ & 0.68 & 1.02 \\
& $\left(4.0 \mu \mathrm{M} \mathrm{Si} \mathrm{d}^{-1}\right)$ & 0.73 & 1.24 \\
P-deficient & $\left(0.2 \mu \mathrm{M} \mathrm{P} \mathrm{d}^{-1}\right)$ & 0.68 & 0.33 \\
& $\left(0.8 \mu \mathrm{M} \mathrm{P} \mathrm{d}^{-1}\right)$ & 0.69 & 0.99 \\
N-deficient & $\left(1.0 \mu \mathrm{MP} \mathrm{d}^{-1}\right)$ & 0.53 & 0.0 \\
& $\left(4.0 \mu \mathrm{MP} \mathrm{d}^{-1}\right)$ & 0.58 & 0.43 \\
\hline
\end{tabular}

were the most important phytoplankton in the northern Adriatic Sea, whereas dinoflagellates were a minor component of the phytoplankton in these waters during late spring and summer months. Some diatom species were favored under P-deficient conditions, while $\mathrm{N}$ deficiency caused some other diatom types to dominate (see Carlsson \& Granéli 1999). Small flagellates were favored by either Si deficiency (because these flagellates do not require $\mathrm{Si}$ as the diatoms do) or by $\mathrm{N}$ deficiency. A surplus of N, P and $\mathrm{Si}$ favored the development of some fast-growing diatoms. 


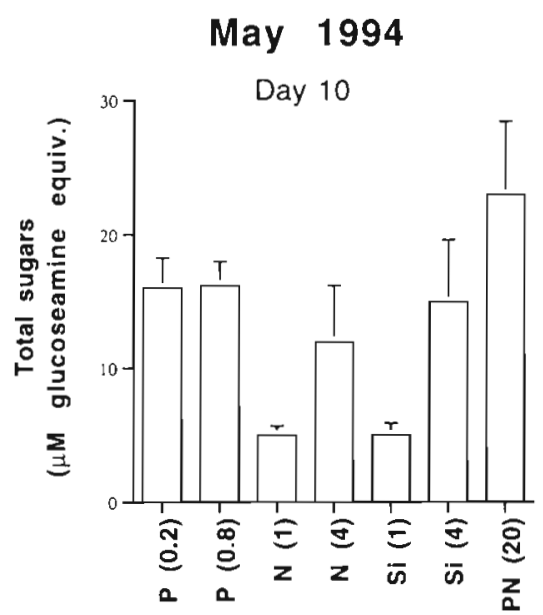

Fig. 7. Total polysaccharides (as $\mu \mathrm{M}$ glucoseamine equivalents) on Day 10 of the May 1994 experiment (histograms are means of 3 replicates; error bars are $\pm 1 \mathrm{SD}$ )

\section{Polysaccharide production}

One of the most important results found in our enclosure experiments was on polysaccharide production during the May 1994 experiment. The highest amount of total polysaccharides produced was under nutrientsufficient and P-deficient conditions (Fig, 7). However, $\mathrm{N}$ deficiency induced the phytoplankton in our cylinders to produce more polysaccharides per cell C or chl a (Fig. 8).

\section{Phytoplankton chemical composition}

The phytoplankton chemical composition changed from the beginning to the end of the experiments. These changes were more accentuated between the different nutrient treatments than between experiments. The POC, PON and POP increased steadily toward the end of the experiments in the nutrient-sufficient conditions and in the treatments where the limiting nutrient was added at the higher levels to the tanks (Figs. 9, $10 \& 11$ ). The exception was when $\mathrm{N}$ was added daily at the lowest concentration $\left(1 \mu \mathrm{mol} \mathrm{I}^{-1} \mathrm{~N} \mathrm{~d}^{-1}\right)$ where POC and PON were found at the lowest concentrations.

\section{DISCUSSION}

The northern Adriatic Sea is considered to be P limited (Pojed \& Kveder 1977, Thingstad \& Rassoulzade-

\section{Phosphorus deficient}

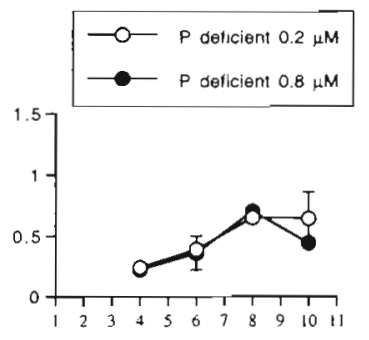

Nitrogen deficient

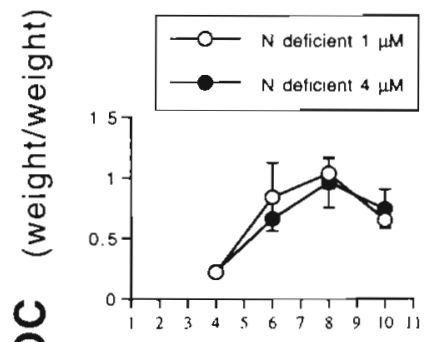

Silicon deficient

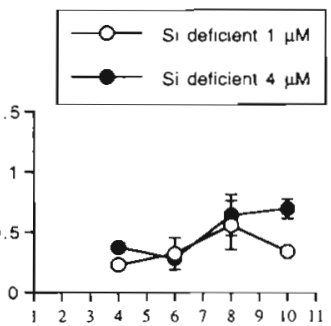

Nutrient sufficient

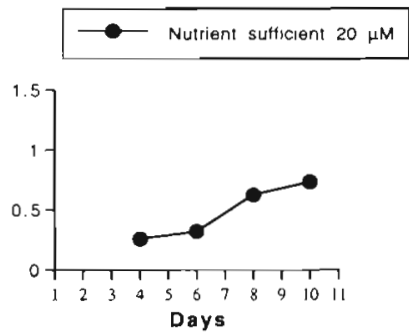

May 1994
Phosphorus deficient

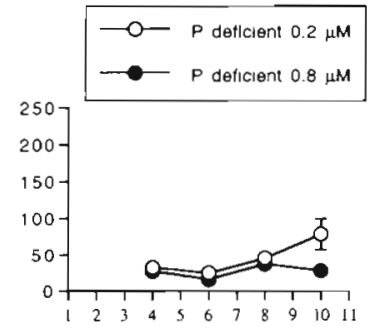

Nitrogen deficient
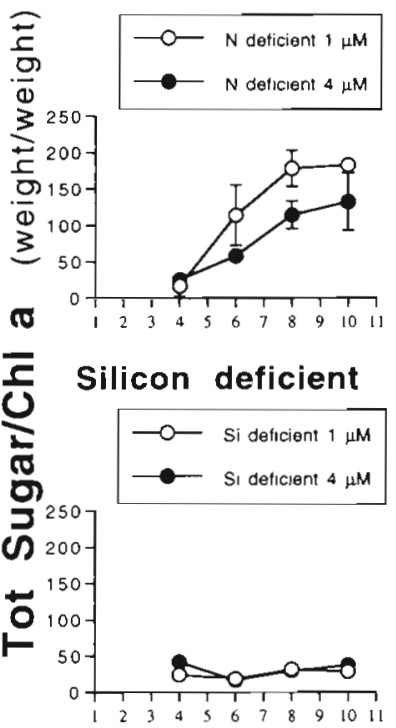

Nutrient sufficient

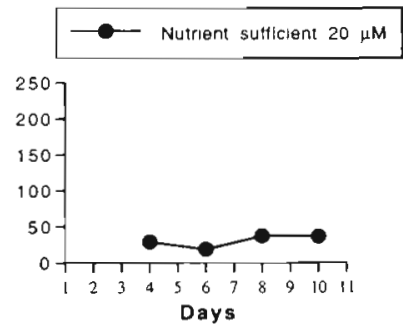

May 1994
Fig. 8. Total polysaccharides:POC (weight: weight) and total polysaccharides:chl a (weight: weight) in the May 1994 experiment (each data point is the mean of 3 replicates; error bars are $\pm 1 \mathrm{SD}$; where no error bars are visible, they are so small that they are hidden by the data points)

gan 1995) and our experiments support this in that $P$ additions in low $\left(0.2 \mu \mathrm{mol} \mathrm{l^{-1 }} \mathrm{P} \mathrm{d}^{-1}\right)$ or high $(0.8$ to $1.3 \mu \mathrm{mol} \mathrm{l^{-1 }} \mathrm{P} \mathrm{d}^{-1}$ ) amounts increased phytoplankton biomass. However, this was only possible when $\mathrm{N}$ was

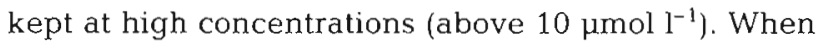
$N$ was added in low concentrations $\left(1 \mu \mathrm{mol} \mathrm{l} \mathrm{l}^{-1} \mathrm{~d}^{-1}\right)$, the resulting phytoplankton biomass was much lower than when $\mathrm{P}$ was added at the low concentrations found in situ during the sampling for the first experiment. In 


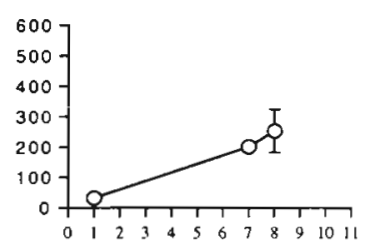

\section{Phosphorus deficient}
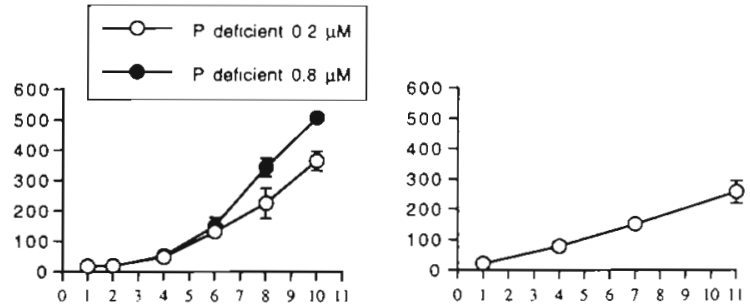

Nitrogen deficient
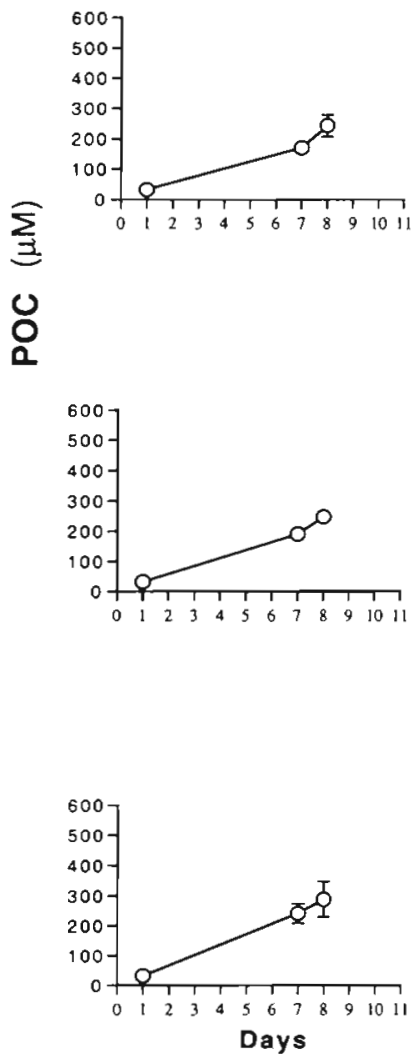

June 1993
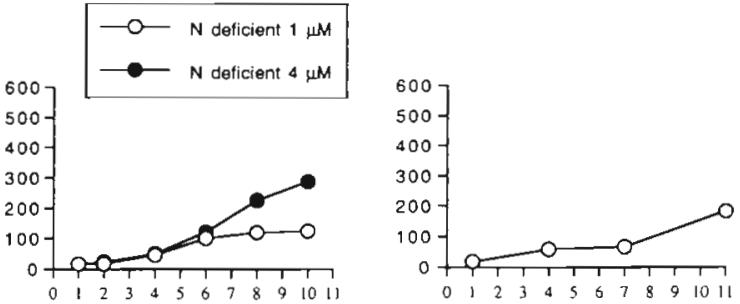

\section{Silicon deficient}
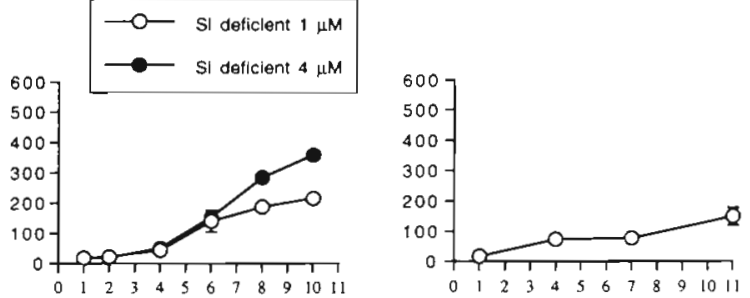

Nutrient sufficient

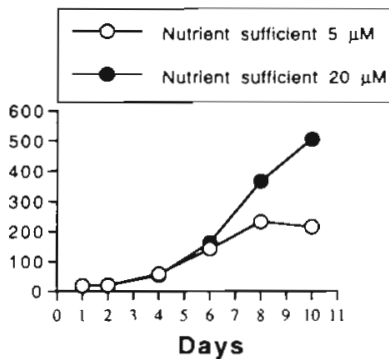

May 1994

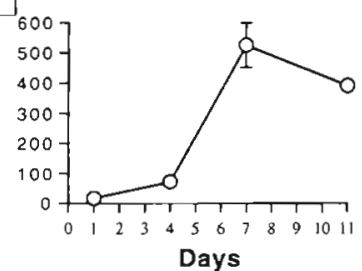

August 1994
Fig. 9. Particulate organic carbon (POC) during the June 1993. May 1994 and August 1994 experiments (each data point is the mean of 3 replicates error bars are $\pm 1 \mathrm{SD}$; where no error bars are visible, they are so small that they are hidden by the data points) terms of environmental policy management, it was only the 'low' levels of $\mathrm{N}$ that could keep the phytoplankton biomass under control.

The phytoplankton was never able to reduce Si concentrations below $0.55 \mu \mathrm{mol} \mathrm{l}^{-1}$, a concentration that was measured from Days 5 to 10 for all treatments with Si-deficiency, and in the N:P:Si 5:0.3:5 treatment. Our measurements of concentrations in standards were performed on artificial seawater, without any problem measuring Si concentrations below these levels. Thus, either the diatoms in the Adriatic were unable to utilize $\mathrm{Si}$ at these concentrations or the cells were not Si lim- ited. The latter might have been the case as diatoms dominated in almost all treatments in all experiments. The concentrations of $\mathrm{Si}$ in the northern Adriatic Sea are between $4.7 \pm 1.5$ and $2.6 \pm 0.9 \mu \mathrm{mol} \mathrm{l}^{-1}$ in surface and intermediate-depth layers, respectively, during summer periods (Franco \& Michelato 1992). This makes it unlikely that Si would ever limit diatom growth in these waters.

Ammonium increased toward the end of the experiments, except for the $\mathrm{N}$-deficient treatment in the August 1994 experiment, when ammonium concentrations were low throughout the entire experiment. This in- 


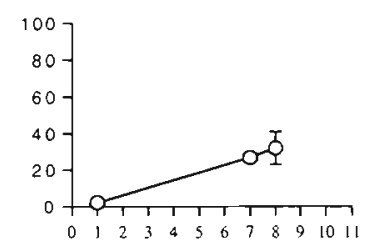

\section{Phosphorus deficient}

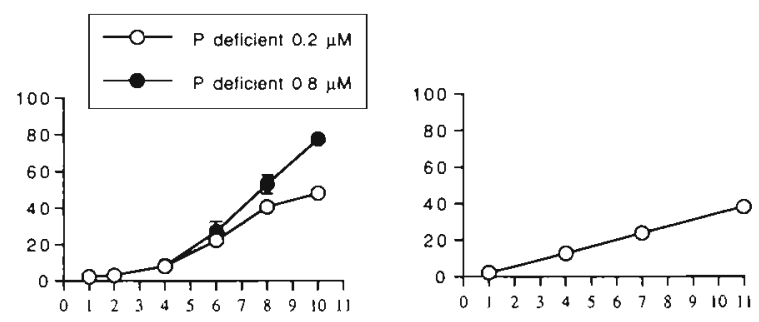

\section{Nitrogen deficient}
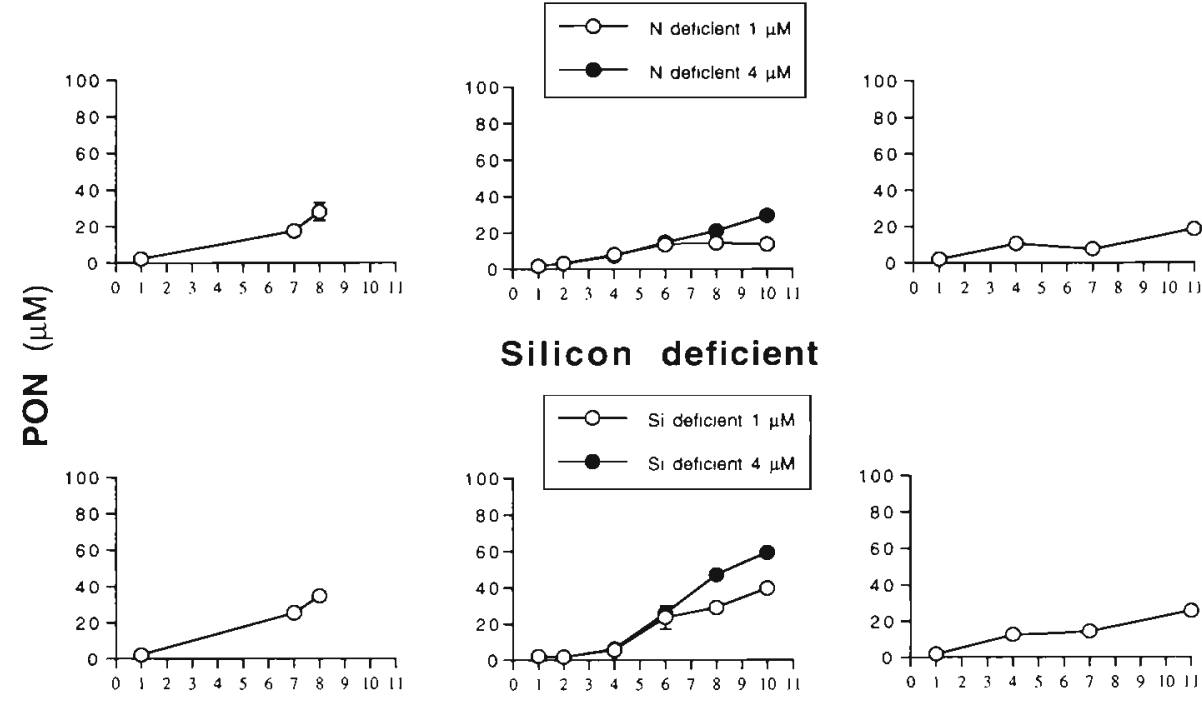

\section{Silicon deficient}
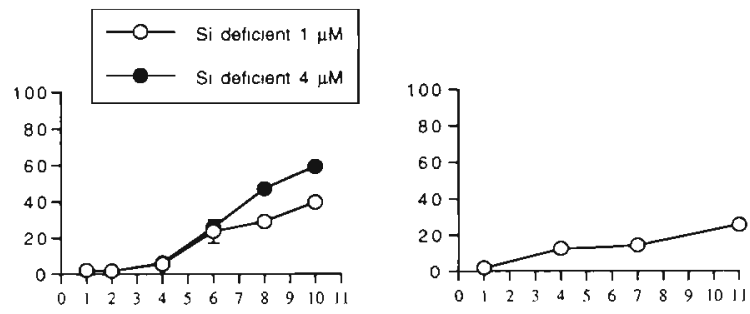

Fig. 10. Particulate organic nitrogen (PON) during the June 1993, May 1994 and August 1994 experiments (each data point is the mean of 3 replicates; error bars are $\pm 1 \mathrm{SD}$; where no error bars are visible, they are so small that they are hidden by the data points)

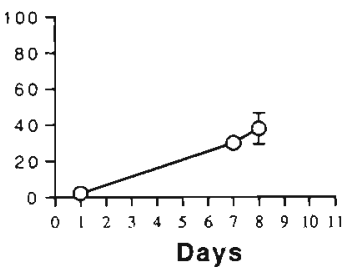

June 1993

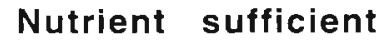

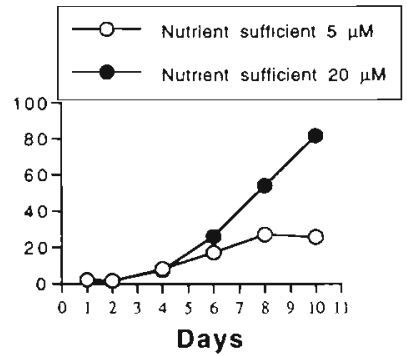

May 1994

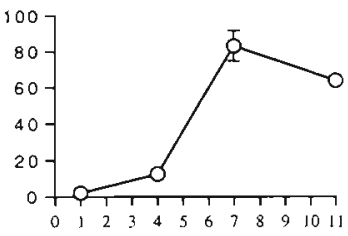

Days
August 1994 crease in ammonium was possibly a result of suboptimal conditions for some of the phytoplankton under different nutrient-deficient conditions, causing higher heterotrophic activity by bacteria and heterotrophic flagellates.

The ratio for the inorganic $\mathrm{N}$ to $\mathrm{P}$ compounds in the Adriatic Sea is usually higher than the Redfield ratio, suggesting that $\mathrm{P}$ could limit the production of phytoplankton biomass (Chiaudani et al. 1980b). Bioassay experiments have confirmed that $\mathrm{P}$ can limit phytoplankton biomass (Chiaudani \& Vighi 1982, Mingazzini et al. 1992). However, extensive field data from the northern Adriatic shows that at almost all times of the year there are high concentrations of both inorganic $N$ and phosphate occurring in the surface water (see $>10$ yr of monitoring data in the reports of Regione Emilia Romagna, Franco \& Michelato 1992). Thus, the normal situation is that neither phosphate nor inorganic $\mathrm{N}$ are totally depleted. The conclusion from this is that the phytoplankton usually will not deplete the water of either inorganic $\mathrm{N}$ or $\mathrm{P}$, even if a high phytoplankton biomass is present. The notion that $\mathrm{P}$ should limit the phytoplankton production is therefore only true during the periods of the year when the phytoplankton have used all the available $P$. 


\section{Phosphorus deficient}
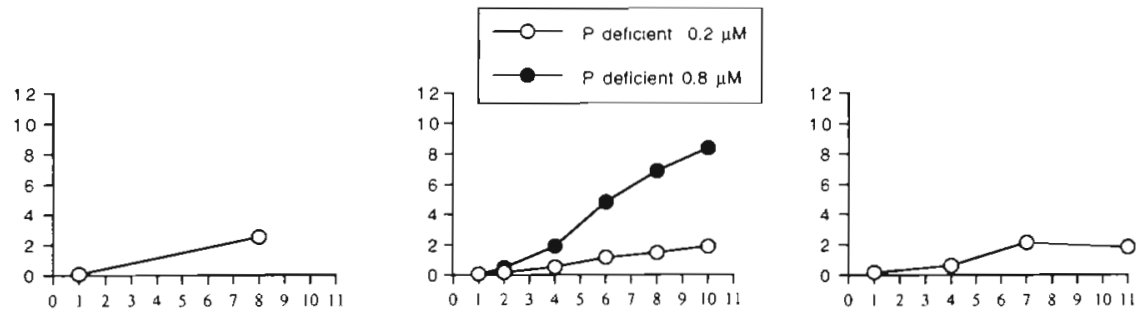

\section{Nitrogen deficient}
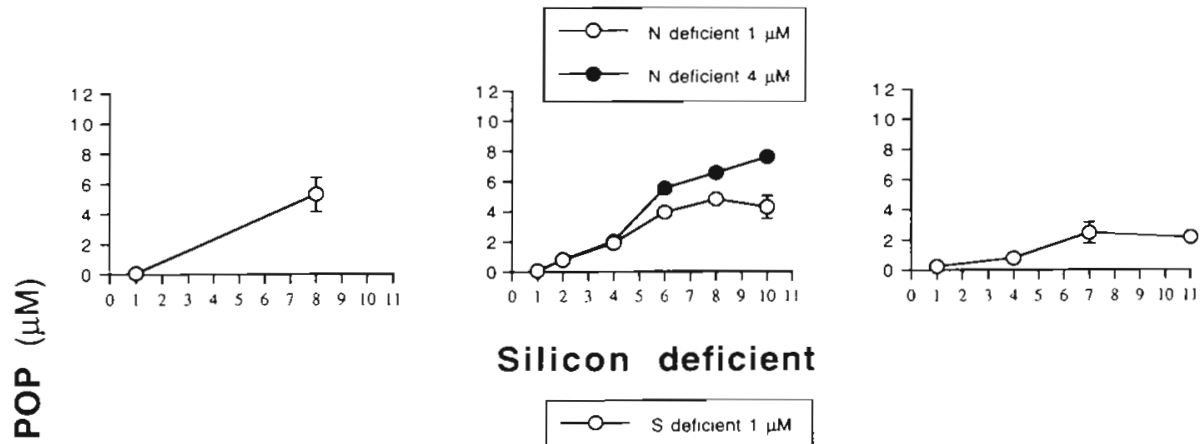

\section{Silicon deficient}
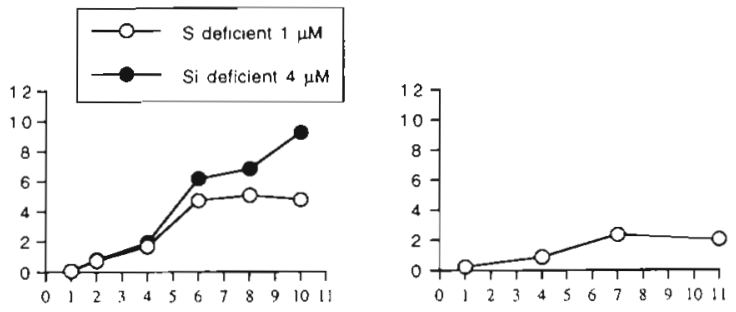

\section{Nutrient sufficient}

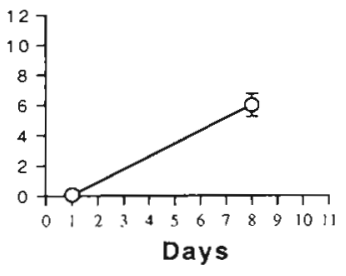

June 1993

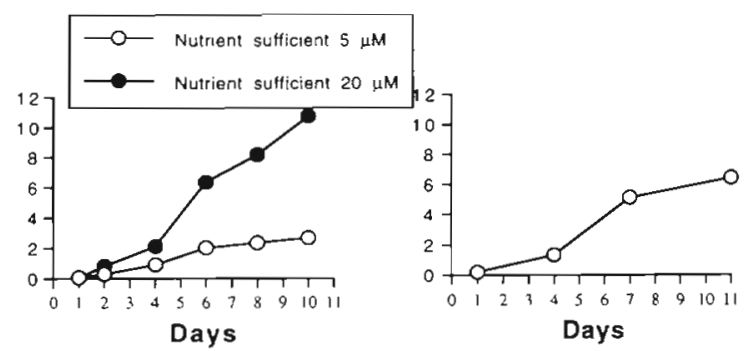

May 1994
August 1994
Fig. 11 Particulate organic phosphorus (POP) during the June 1993, May 1994 and August 1994 experiments (each data point is the mean of 3 replicates; error bars are $\pm 1 \mathrm{SD}$; where no error bars are visible, they are so small that they are hidden by the data points)
Why then are neither phosphate nor inorganic $\mathrm{N}$ fully utilized during most of the growth season? The explanation for this may be that the phytoplankton cells are removed from the water column faster than they grow, either by zooplankton grazing or by the filtration activity from the benthos. The grazing experiments in our study (see Turner et al. 1999) showed that even 10 times higher than normal mesozooplankton abundance could not curtail phytoplankton growth in our enclosures, and that the phytoplankton ultimately have the potential to use all inorganic nutrients present. Therefore it seems that zooplankton grazing is a minor factor limiting phytoplankton depletion of the inorganic nutrients in the northern Adriatic Sea. Alternatively, the filtration activity of the benthos is potentially substantial, and it has been shown that all phytoplankton can be removed from a $10 \mathrm{~m}$ deep, well-mixed water column by the benthic suspension feeders in 1 to $3 \mathrm{~d}$ in Scandinavian waters (Loo \& Rosenberg 1989). Perhaps in the shallow northern part of the Adriatic Sea, the high biomass of benthic suspension feeders may have the capacity to remove such large quantities of phytoplankton that no real limitation of either $\mathrm{N}$ or P normally occurs. 


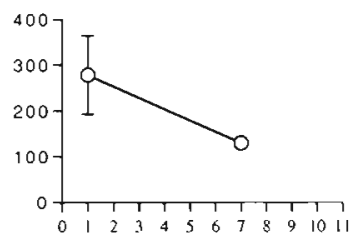

\section{Phosphorus deficient}

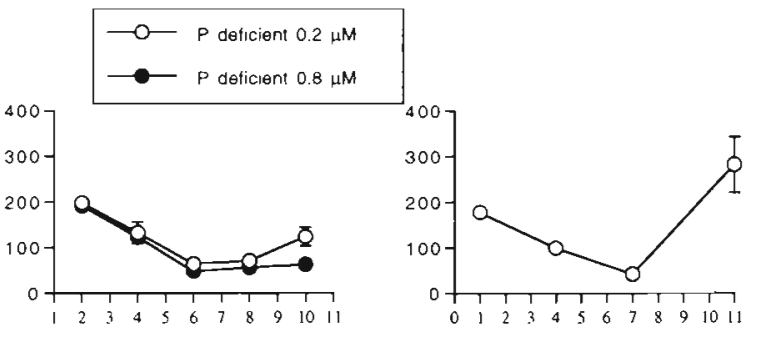

Nitrogen deficient

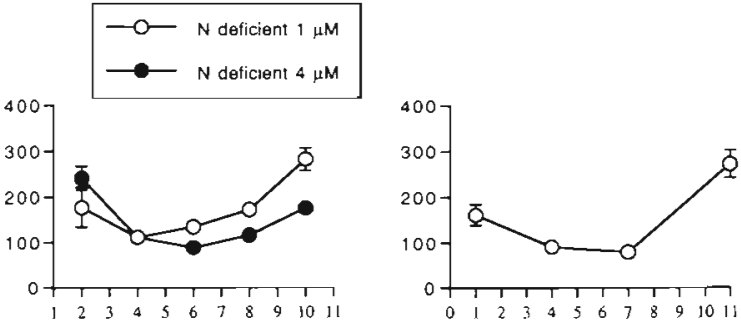

Silicon deficient

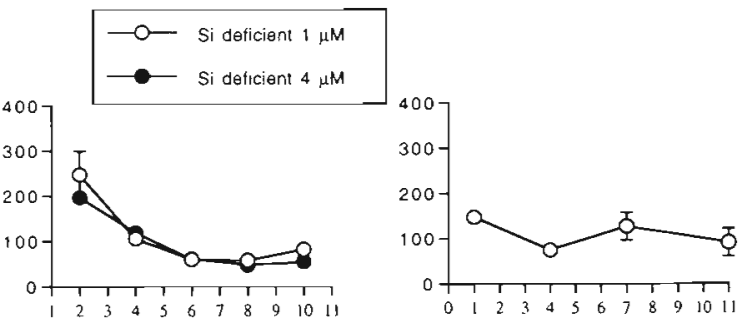

Nutrient sufficient

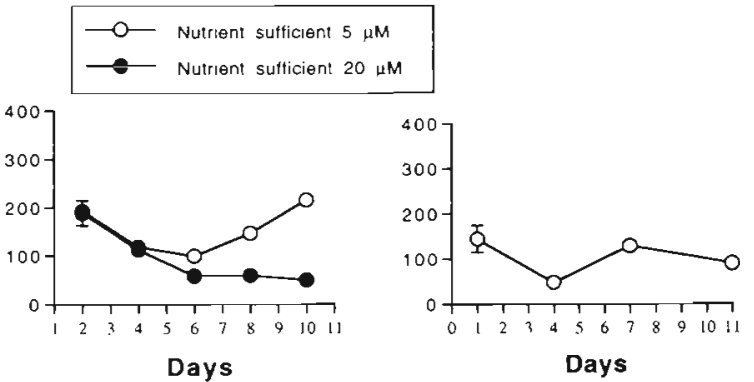

May 1994

August 1994

In our experiments, diatom growth was likely only marginally affected by low Si concentrations in the Sideficient treatments. This can be seen in the POC:chl a ratios (Fig. 12), which were always below 100, indicating healthy, growing cells (Goldman 1980), and in the high growth rates, based on increases in chl $a$, which were always $>1 \mathrm{~d}^{-1}$ (Table 2 ). In the Si-deficient treatments, diatoms used the Si that was added each day such that silicate concentrations were reduced to 0.5 to $0.6 \mu \mathrm{mol} \mathrm{l}^{-1}$ the day after additions. This is in the range of, or slightly higher than, reported half saturation constants for various marine diatoms of 0.02 to $0.5 \mu \mathrm{mol} \mathrm{l}^{-1}$
(Paasche 1980). The conclusion is that the diatoms could grow quite well in our experiments in spite of low Si concentrations. In the June 1993 experiment, however, diatoms were not so numerous in the initial community, and increased in treatments with high Si addition. However, the small autotrophic flagellates kept their dominance in the Si-deficient treatment, indicating that lack of Si could restrain the growth of diatoms in this experiment (see Carlsson \& Granéli 1999).

Different diatom species have been shown to have different demands for Si compared to $\mathrm{P}$ ( $\mathrm{Si}: \mathrm{P}=96: 1$ to $1: 1$, Kilham \& Hecky 1988). If we assume that the N:P 
demand is 16:1 (Redfield ratio), then diatoms with a low Si:P demand (around 1) would need very small amounts of Si compared to $\mathrm{N}$.

In the P-deficient treatment with the highest daily $\mathrm{P}$ addition $\left(0.8 \mu \mathrm{mol} \mathrm{l}^{-1} \mathrm{~d}^{-1}\right)$, the phytoplankton never became P-deficient (POC:chl a was always below 100) (Fig. 12).

\section{Growth rates and phytoplankton chemical composition}

Nutrient deficiency or sufficiency in phytoplankton is not only defined by the nutrient concentrations and ratios in the medium where the phytoplankton are growing, but also in terms of the intracellular chemical composition. The latter gives a better indication nutrient limitation (Droop 1974). Many studies using cultures have shown that it is difficult to relate phytoplankton growth rates to external nutrient concentrations, and that growth rates are related instead to the internal nutrient conditions (Hecky \& Kilham 1988 and references therein).

Different chemical compositions (C:N:P) between and within different algal groups may explain differences in composition of particulate material between different treatments in our experiments (Healy \& Hendzel 1979, Hecky \& Kilham 1988). Also, luxury consumption of $\mathrm{P}$ may give very low N:P ratios (Mackereth 1953, Reynolds 1984).

Some phytoplankton species appear to be uptake specialists, whereas others are storage specialists (Tilman et al. 1982, Sommer 1986). The pulsed addition of nutrients in our experiment should have been beneficial to the species adapted to rapidly take up nutrient pulses.

In our experiments, as expected, the POC:chl a ratios were very high in the $\mathrm{N}$-deficient cylinders (lowest = 80:1, weight basis in August 1994). This indicates that the cells were $\mathrm{N}$-starved and unable to build up chl a due to the lack of $N$. Goldman (1980) proposed that such low values could not support growth rates $(\mu)$ above 0.1 . Indeed $\mu$ was zero in the May, $1994 \mathrm{~N}$-deficient cylinders where $1 \mu \mathrm{mol} \mathrm{l}^{-1} \mathrm{~N}$ was added daily, but 0.43 in the $\mathrm{N}$-deficient treatment where $4 \mu \mathrm{mol} \mathrm{l^{-1 }} \mathrm{N}$ was added daily, although the $\mathrm{POC}: \mathrm{chl}$ a ratio was above 100 in both treatments in August 1994

The ratios of C:N:P showed a different pattern from their concentrations in the particulate material. Duarte (1992), comparing intracellular concentrations and ratios for C:N:P for 96 phytoplankton species from the literature, found that there was a broad range of variation for the ratios of these elements. Carbon was the element showing the highest variability for the different groups. Diatoms had the lowest concentrations while the highest were found for dinoflagellates and green algae. The explanation seems, at least for dinoflagellates, to be the thick cell wall of cellulose (Sakshaug et al. 1984). In our cylinders diatoms made up the bulk of the biomass in most experiments. Thus, the variations in our ratios were not as large as those found by Duarte (1992). The variations in C:N:P ratios in our tanks mostly depended upon whether the phytoplankton were nutrient limited or not, and the values differed maximally by about 2 -fold. For instance, PON:POC and POP : $P O C$ ratios either remained at the same levels or decreased in the nutrient-deficient treatments. This occurred in the N-and P-deficient cylinders for the May 1994 and August 1994 experiments. This suggests that the phytoplankton in these treatments were growing suboptimally due to $\mathrm{N}$ or $\mathrm{P}$ limitation, and accumulating excess $C$ from photosynthesis at the same time.

The PON:chl $a$ and POP:chl a ratios (Figs. 13 \& 14) decreased from high initial values to low ones during the middle of the experiments. These ratios increased again most markedly in the $\mathrm{N}$ - and $\mathrm{P}$-deficient treatments, although less markedly in the latter. Silicon deficiency did not provoke such strong response in the phytoplankton cells. The reason seems to be that, even if the diatoms made up the bulk of the phytoplankton biomass in all the containers, they could grow at low $\mathrm{Si}$ concentrations without suffering from severe Si deficiency. This is also supported by the fact that the POP: POC or PON:POC ratios in the Si-deficient treatments did not increase markedly at the end of the experiments. The decrease seen in the POP : chl $a$ and PON:chl a ratios indicates that initially there was a pool of PON (between 1.5 to $2.9 \mu_{\mathrm{mol} \mathrm{l}}^{-1}$ ) and POP (between 0.3 and $0.8 \mu \mathrm{mol} \mathrm{\textrm {I } ^ { - 1 }}$ ) which probably was not in the phytoplankton but rather in detritus.

The POC: chl a ratios were also higher initially in all treatments, indicating that a substantial pool of detritus or other particulate material unrelated to the phytoplankton was present. However, after a few days when the phytoplankton biomass increased, these ratios reached levels considered to be normal for nonnutrient-limited phytoplankton cells (between 40 and 60 on a weight basis). Toward the end of the experiments these ratios increased again. Inorganic nutrient concentrations in the tanks during the experiments in May 1994 and August 1994 suggested that the phytoplankton cells were nutrient limitated in the P- and $\mathrm{N}$ deficient cylinders. However, in the June 1993 experiment the POC: chl a ratios did not increase at all. This experiment was different from the others, however, in that after the fifth day we did not mix the water in the cylinders before sampling. Samples were taken both from the surface water and sedimented material in an attempt to see if mucilage was being produced by sedimenting diatoms during stable conditions. We did not observe any mucilage formation by the sedimenting diatoms, however, in any of the treatments. 
Fig. 13. PON:chl a ratios during the June 1993, May 1994 and August 1994 experiments (each data point is the mean of 3 replicates; error bars are $\pm 1 \mathrm{SD}$; where no error bars are visible, they are so small that they are hidden by the data points)
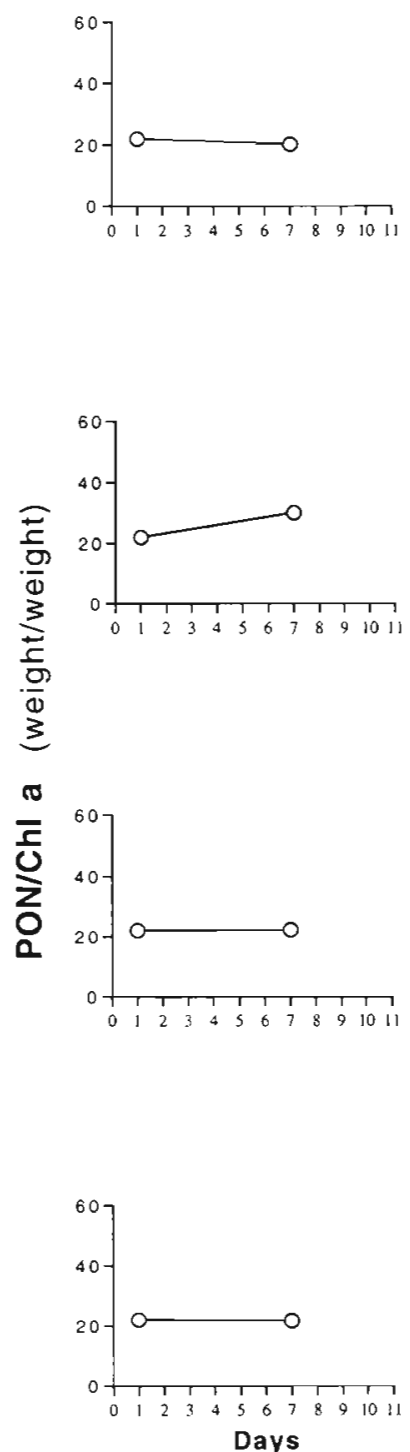

June 1993
Phosphorus deficient

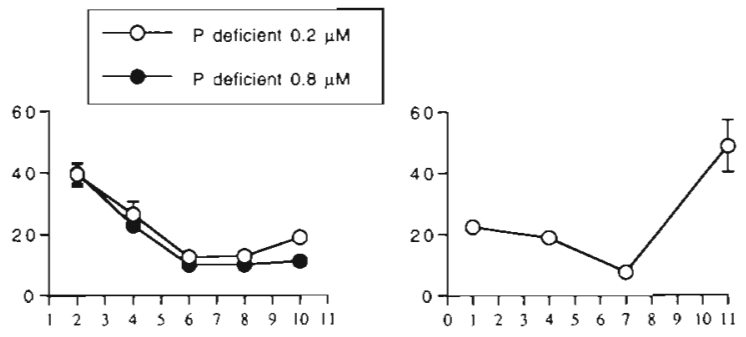

Nitrogen deficient
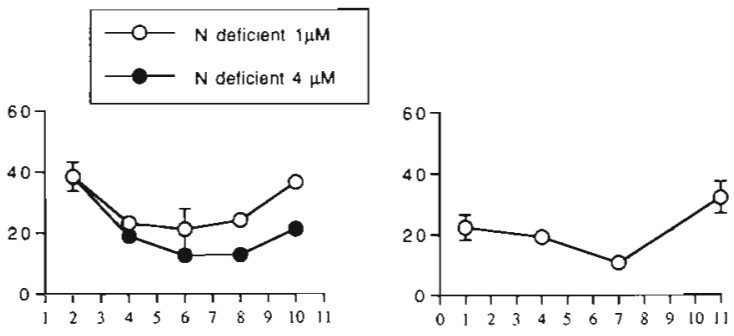

Silicon deficient
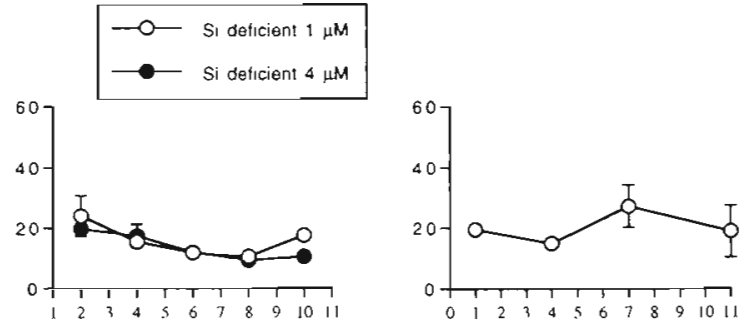

Nutrient sufficient

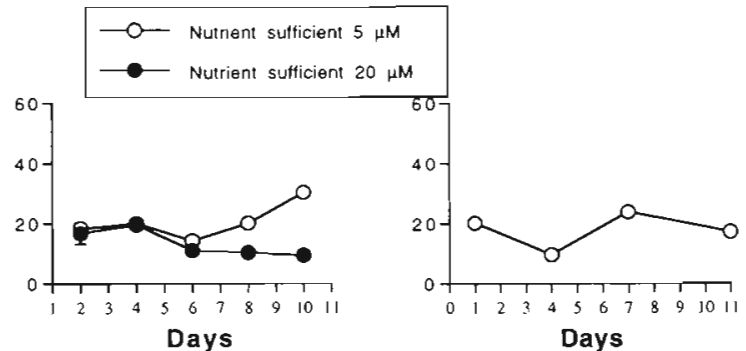

May 1994
August 1994

\section{Polysaccharide production}

The mucilage formation in the northern Adriatic Sea has long been believed to be due to exudates of benthic diatoms (Forti 1906, Zanon 1931). Conversely, Degobbis (1995) collected information from several independent sources and came to the conclusion that mucilage is a result of polysaccharide production by pelagic and not benthic diatoms. This theory fits well with our results. The phytoplankton in our cylinders during the May 1994 experiment was dominated by pelagic diatoms, and they were able to produce high quantities of polysaccharides. We do not know whether benthic diatoms would produce the same amount or even more, since benthic diatoms did not comprise a substantial part of the microalgae biomass.

The higher amounts of polysaccharides produced per unit of cell $\mathrm{C}$ were under $\mathrm{N}$-deficiency. This agrees with reports from elsewhere which show that exudate production is stimulated when the algae are first subjected to high N:P ratios, and thereafter are subjected to low nutrient concentrations (Myklestad 1977, Monti 


\section{Phosphorus deficient}
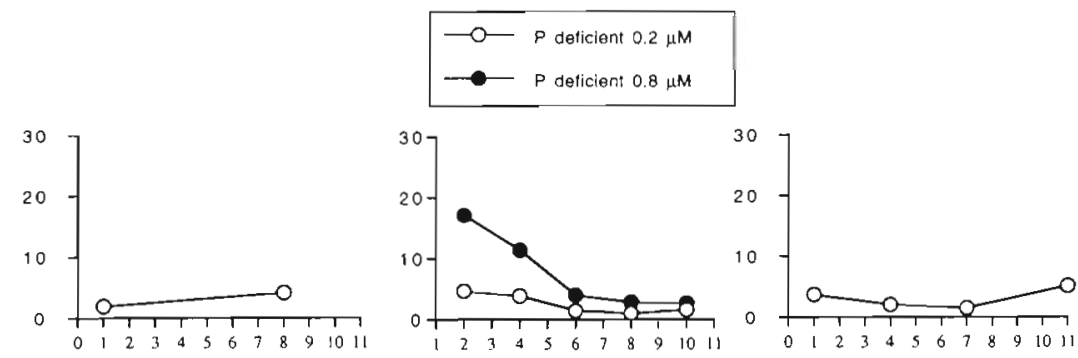

\section{Nitrogen deficient}
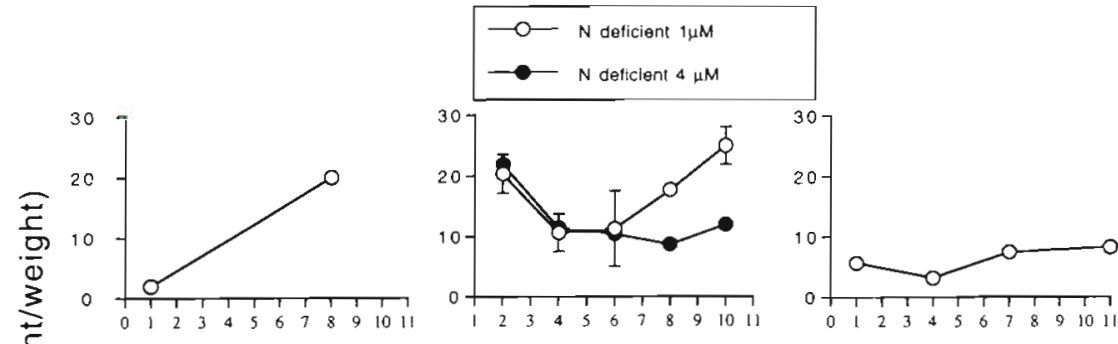

\section{Silicon deficient}
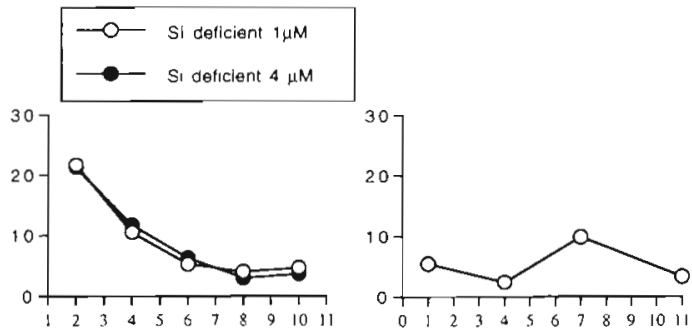

\section{Nutrient sufficient}
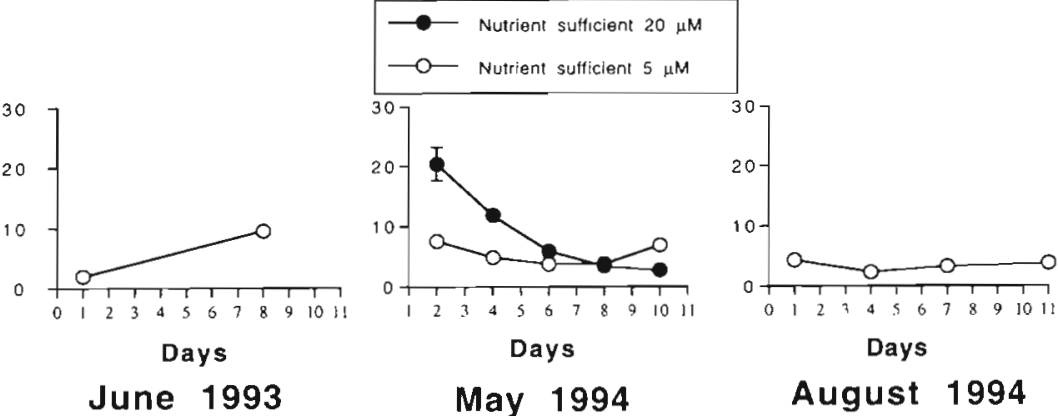

Fig. 14. POP:chl a ratios during the June 1993. May 1994 and August 1994 experiments (each data point is the mean of 3 replicates; error bars are $\pm 1 \mathrm{SD}_{i}$ where no error bars are visible, they are so small that they are hidden by the data points)

et al. 1995). Thus, as Degobbis (1995) suggested, the high production of polysaccharides seems to be related to runoff pulses (mostly from the Po river), followed by a period with nutrient depletion.

\section{Conclusions}

The input of inorganic nutrients ( $\mathrm{N}$ and $\mathrm{P}$ ) to coastal areas of the northern Adriatic Sea appears to be sufficient to produce the large algal biomass responsible for the large production of polysaccharides seen in the area. This is despite the fact that $P$ is in 'limiting' amounts in relation to the 16:1 optimal Redfield ratio for $N$ and $P$ thought to be beneficial for phytoplankton growth. Since a low daily addition of $\mathrm{P}$ produced approximately double the biomass of phytoplankton compared to an equivalent Redfield $\mathrm{N}$ addition, only when a high concentration of inorganic $N$ was present, we suggest that a reduction of $\mathrm{N}$ discharges to the northern Adriatic Sea would result in a reduced eutrophication situation in the area. The anomalous production of phytoplankton induced by $\mathrm{P}$ addition compared to $\mathrm{N}$ addition may well be caused by the fast recycling of $P$. 
Acknowledgements. Funding was from the EEC (European Economic Community), contract no. EV5V-CT92-0215 MARE Project, and the funds were made available through the Swedish Environmental Protection Agency. We appreciate the assistance of Simonetta della Libera, Rafaele Scenati. Giovanni Costamagna, and Milena Bruno (Istituto Superiore di Sanita, Rome), Ludovica Diliberto (Centro di Ricerca e Formazione per il Controllo dei Sistemi Idrici, Sardegna) and the staff of the Istituto Zooprofilatico Delle Umbria e de La Marche, Fano. Farooq Azam provided valuable criticism of the manuscript.

\section{LITERATURE CITED}

Ertebjerg-Nielsen G, Bresta AM (eds) (1984) The Baltic marine biologists. Guidelines for the measurement of phytoplankton primary production. BMB Publ no. 1, 2nd edn. Marine Pollution Laboratory, Charlottenlund

Berland BR, Bonin DJ, Maestrini SY (1980) Azote ou phosphore? Considérations sur le 'paradoxe nutritionnel' de la mer méditerranée. Oceanol Acta 3:135-142

Boni L, Milandri A, Poletti R, Pompei M (1993) DSP-cases along the Emiglia-Romagna coast (Northwestern Adriatic Sea). In: Smayda TJ, Shimizu Y (eds) Toxic phytoplankton blooms in the sea. Elsevier, Amsterdam, p 475-481

Caraco N, Cole J, Likens GE (1990) A comparison of phosphorus immobilization in sediments of freshwater and coastal marine systems. J Biochem 9:277-290

Carlsson P, Granéli E (1999) Effects of N:P:Si ratios and zooplankton grazing on phytoplankton communities in the northern Adriatic Sea. II Phytoplankton species composition. Aquat Microb Ecol 18:55-65

Cati L (1981) Idrografia e idrologia del Po. Pubbli Ufficio Idrografico del Po, Ministero Lavori Pubblici, Rome

Chiaudani G, Vighi M (1982) Multistep approach to identification of limiting nutrients in Northern Adriatic eutrophied waters. Water Res 21:219-229

Chiaudani G, Marchetti R, Vighi M (1980a) Eutrophication in Emilia-Romagna coastal waters (North Adriatic Sea, Italy): a case history. Prog Wat Technol 12:185-192

Chiaudani G, Gaggino GF, Vighi M (1980b) Nutrient limitation assessment in Emilia-Romagna eutrophicated coastal waters. In: Workshop on pollution of the Mediterranean. Proc ICSEM/UNEP, Cagliari, p 383-390

Dawson R, Liebezeit G (1981) The analytical methods for the characterisation of organics in seawater. In: Duursma EK Dawson R (eds) Marine organic chemistry. Evolution, composition interactions and chemistry of organic matter in seawater. Elsevier Oceanography Series 31:463-465

Degobbis D (1989) Increased eutrophication of the Northern Adriatic Sea. Mar Pollut Bull 20:452-457

Degobbis D (1995) Increased eutrophication of the Northern Adriatic Sea-second act. Mar Pollut Bull 9:452-457

Degobbis D, Gilmartin M (1990) Nitrogen, phosphorus, and biogenic silicon budgets for the Northern Adriatic Sea. Oceanol Acta 13:31-45

Droop MR (1974) The nutrient status of algal cells in continuous culture. J Mar Biol Assoc UK 54:825-855

Duarte CM (1992) Nutrient concentration of aquatic plants: patterns across species. Limnol Oceanogr 37:882-889

Fonda Umani S, Franco P, Ghirardelli E, Malej A (1993) Outline of oceanography and the plankton of the Adriatic Sea. In: Colombo G, Ferrari I, Ceccherelli VU, Rossi R (eds) Marine eutrophication and population dynamics. Proc 25th Eur Mar Biol Symp. Olsen \& Olsen, Fredensborg, p $347-365$
Forti A (1906) Alcune osservazioni sul 'mare sporco' ed in particolare sul fenomeno avvenuto nel 1905. Nouvo G Bot Ital (NS) 13:1-56

Franco P, Michelato A (1992) Northern Adriatic Sea: oceanography of the basin proper and of the western coastal zone. In: Vollenweider RA, Marchetti R, Viviani R (eds) Marine coastal eutrophication. Elsevier, New York, p 36-52

Gilmartin M, Revelante N (1980) Nutrient input and the summer nanoplankton bloom in the Northern Adriatic Sea. PSZN I: Mar Ecol 1:169-180

Goldman JC (1980) Physiological processes, nutrient availability and the concept of relative growth rate in marine phy toplankton ecology. Brookhaven Symp Biol 31:179-194

Granéli E, Wallström K, Larsson U, Granéli W, Elmgren R (1990) Nutrient limitation of primary production in the Baltic Sea area. Ambio 19:142-151

Guillard RRL, Ryther JH (1962) Studies of marine planktonic diatoms I Cyclotella nana Hustedt, and Detonula confervacea (Cleve) Gran. Can J Microbiol 8:229-239

Healy FP, Hendzel LL (1979) Indicators of phosphorus and nitrogen deficiency in five algae in culture. J Fish Res Board Can 36:1364-1369

Hecky RE, Kilham P (1988) Nutrient limitation of phytoplankton in freshwater and marine environments: a review of recent evidence on the effects of enrichment. Limnol Oceanogr 33:796-822

Howarth RW (1988) Nutrient limitation of net primary production in marine ecosystems. Ann Rev Ecol 19:89-110

Jespersen AM, Christoffersen K (1987) Measurements of chla from phytoplankton using ethanol as extraction solvent. Arch Hydrobiol 109:445-454

Justic D (1987) Long-term eutrophication of the Northern Adriatic Sea. Mar Pollut Bull 18:281-284

Justic D (1991) A simple oxygen index of trophic state description. Mar Pollut Bull 22:201-204

Kilham P, Hecky RE (1988) Nutrient limitation of phytoplankton in freshwater and marine environments: a review of recent evidence on the effects of enrichment. Limnol Oceanogr 33:776-795

Likens GE (ed) (1972) Nutrients and eutrophication: the limiting-nutrient controversy. Am Soc Limnol Oceanogr Spec Symp. Allen Press, Inc, Lawrence, KS

Loo LO, Rosenberg R (1989) Bivalve suspension-feeding dynamics and benthic-pelagic coupling in an eutrophicated marine bay. J Exp Mar Biol Ecol 130:253-276

Mackereth FJH (1953) Phosphorus utilization by Asterionella formosa Has. J Exp Bot 4:296-313

Malej A, Mozetic P, Malacic V, Terzic S, Ahel M (1995) Phytoplankton responses to freshwater inputs in a small semienclosed gulf (Gulf of Trieste, Adriatic Sea). Mar Ecol Prog Ser 120:111-121

Marchetti R (1992) The problems of the Emilia Romagna coastal waters: facts and interpretations. In: Vollenweider RA, Marchetti R, Viviani R (eds) Marine coastal eutrophication. Elsevier, Amsterdam, p 21-33

Mingazzini M, Rinaldi A, Montanari G (1992) Multi-level nutrient enrichment bioassays on Northern Adriatic coastal waters. In: Vollenweider RA, Marchetti R, Viviani $\mathrm{R}$ (eds) Marine coastal eutrophication. Elsevier, Amsterdam, p 115-131

Monti M. Welker C, Dellavalle G, Casaretto L, Fonda-Umani $S$ (1995) Mucous aggregates under natural and laboratory conditions: a review. Sci Total Environ 165:145-154

Myklestad S (1977) Production of carbohydrates by marine phytoplanktonic diatoms. II Influence of the N/P ratio in the growth medium on the assimilation ratio, growth rate, and production of cellular and extracellular carbohydrates 
by Chaetoceros affinis var. Willei (Gran) Hustedt and Skeletonema costatum (Grev.) Cleve. J Exp Mar Biol Ecol 29:161-179

Nixon SW (1990) Marine eutrophication: a growing international problem. Ambio 19:1-176

Olsson P, Granéli E, Carlsson P, Abreu P (1992) Structuring of a postspring phytoplankton community by manipulation of trophic interactions. J Exp Mar Biol Ecol 158: $249-266$

Oviatt C, Doering P, Nowicki B, Reed L, Cole J, Frithsen J (1995) An ecosystem level experiment on nutrient limitation in temperate coastal marine environments. Mar Ecol Prog Ser 116:171-179

Paasche E (1980) Silicon. In: Morris I (ed) The physiological ecology of phytoplankton. Blackwell, Oxford, p 259-284

Piccinetti C, Manfrin G (1969) Osservazioni sulla mortalita di pesci e di altri organismi verificatasi nel 1969 in Adriatico. Note Lab Biol Mar Pesca-Fano 3:73-92

Pojed I, Kveder S (1977) Investigation of nutrient limitation of phytoplankton production in the North Adriatic by enrichment experiments. Thalassia Jugosl 13:13-24

Reynolds CS (ed) (1984) The ecology of freshwater phytoplankton. Cambridge studies in ecology. Cambridge University Press, Cambridge

Ryther JH, Dunstan WM (1971) Nitrogen, phosphorus and eutrophication in the coastal marine environment. Science 171:1008-1013

Sakshaug E, Granéli E, Elbrächter M, Kayser H (1984) Chemical composition and alkaline phosphatase activity of nutrient-saturated and P-deficient cells of four marine dinoflagellates. J Exp Mar Biol Ecol 77:241-254

Schöne HK, Schöne A (1982) A weakly enriched sea-water medium for ecological studies on marine plankton algae, some examples of its application. Bot Mar 25:117-122

Editorial responsibility: John Dolan,

Villefranche-sur-Mer, France
Smith SV (1984) Phosphorus versus nitrogen limitation in the marine environment. Limnol Oceanogr 29:1149-1160

Solórzano L, Sharp JH (1980) Determination of total dissolved phosphorus and particulate phosphorus in natural waters. Limnol Oceanogr 25:754-758

Sommer U (1986) Phytoplankton competition along a gradient of dilution rates Oecologia 68:503-506

Stachowitsch M, Fanuko N, Richter M (1990) Mucus aggregates in the Adriatic Sea: an overview of stages and occurrences. PSZN I: Mar Ecol 11:327-350

Thingstad TF, Rassoulzadegan F (1995) Nutrient limitation, microbial food webs, and 'biological C-pumps': suggested interactions in a P-limited Mediterranean. Mar Ecol Prog Ser 117:299-306

Tilman D, Kilham SS, Kilham P (1982) Phytoplankton community ecology: the role of limiting resources. Annu Rev Ecol Syst 13:349-372

Turner JT, Tester PA, Lincoln JA, Carlsson P, Granéli E (1999) Effects of N:P:Si ratios and zooplankton grazing on phytoplankton communities in the northern Adriatic Sea. III. Zooplankton populations and grazing. Aquat Microb Ecol $18: 67-75$

Valderrama JC (1995) Methods of nutrient analysis. In: Hallegraeff GM, Anderson DM, Cembella AD (eds) Manual of harmful marine microalge. IOC Manuals and Guides No. 33, UNESCO Workshop, Paris, p 251-268

Vollenweider RA, Rinaldi A, Montanari G (1992) Eutrophication, structure and dynamics of a marine coastal system: results of ten-year monitoring along the Emilia-Romagna coast (Northwest Adriatic Sea). In: Vollenweider RA, Marchetti R, Viviani R (eds) Marine coastal eutrophication. Elsevier, Amsterdam, p 63-106

Zanon DV (1931) Esame di un campione di 'mare sporco' del Golfo di Fiume. Mem Pont Acad Lincei 15:1-33

Submitted: September 22, 1997; Accepted: October 29, 1998 Proofs received from author(s): July 12, 1999 